OPEN ACCESS

Edited by:

Elsa Lamy,

University of Évora, Portugal

Reviewed by: loannis S. Pappas,

University of Thessaly, Greece

F. Capela e Silva,

University of Evora, Portugal

*Correspondence:

Tarique Hussain

drtariquerahoo@gmail.com

Specialty section:

This article was submitted to Animal Nutrition and Metabolism,

a section of the journal

Frontiers in Veterinary Science

Received: 01 October 2021

Accepted: 13 December 2021

Published: 03 March 2022

Citation:

Afzal A, Hussain T, Hameed A, Shahzad M, Mazhar MU and Yang G (2022) Dietary Moringa oleifera Alters

Periparturient Plasma and Milk Biochemical Indicators and Promotes Productive Performance in Goats.

Front. Vet. Sci. 8:787719. doi: 10.3389/fvets.2021.787719

\section{Dietary Moringa oleifera Alters Periparturient Plasma and Milk Biochemical Indicators and Promotes Productive Performance in Goats}

\author{
Ali Afzal ${ }^{1}$, Tarique Hussain ${ }^{1 *}$, Amjad Hameed ${ }^{2}$, Muhammad Shahzad ${ }^{1}$, \\ Muhammad Usman Mazhar ${ }^{1}$ and Guan Yang ${ }^{3}$
}

${ }^{1}$ Animal Sciences Division, Nuclear Institute for Agriculture and Biology College, Pakistan Institute of Engineering and Applied Sciences (NIAB-C, PIEAS), Faisalabad, Pakistan, ${ }^{2}$ Nuclear Institute for Agriculture and Biology College, Pakistan Institute of Engineering and Applied Sciences (NIAB-C, PIEAS), Faisalabad, Pakistan, ${ }^{3}$ Department of Infectious Diseases and Public Health, City University of Hong Kong, Kowloon, China

The purpose of the current study was to explore the supplementing effects of Moringa oleifera leaf powder (MOLP) on plasma and milk biochemical indices and productive/reproductive performance of goats. A total of 30 healthy pregnant goats were randomly distributed $(n=10)$ into three experimental groups: control $\left(M_{0}\right)$ group (basal diet without MOLP), $M_{2 \%}$ group (basal diet $+2 \%$ MOLP), and $M_{3.5 \%}$ group (basal diet + 3.5\% MOLP). The experiment started 2 months before parturition and continued till the first month of lactation. The plasma flavonoids were significantly increased in the $M_{3.5 \%}$ group during the entire experiment, whereas the total phenolic contents were enhanced only during the lactation period depending on the supplementation percentage. The amount of vitamin $C$ increased significantly in $M_{2 \%}$ and $M_{3.5 \%}$ groups as compared to the $M_{0}$ group. Supplementation of MOLP improved the plasma total antioxidant capacity by declining malondialdehyde concentration and total oxidant status values. The activities of superoxide dismutase and peroxidase enzymes were modified in $\mathrm{M}_{2 \%}$ and $\mathrm{M}_{3.5 \%}$ supplemented groups throughout the experiment, while the catalase activity was significantly influenced only during the lactation stage. The protein and lycopene contents in plasma were significantly improved in the $M_{3.5 \%}$ group, whereas the total sugars and carotenoid level was increased in both $M_{2 \%}$ and $M_{3.5 \%}$ groups. Dietary supplementation with 3.5\% MOLP more effectively enhanced protease and amylase activities as compared to $2 \%$ supplementation. MOLP also improved the biochemical indices and antioxidant status of colostrum and milk. The milk yield, weight gain of the kids, and reproductive performance were high in $\mathrm{M}_{2 \%}$ and $\mathrm{M}_{3.5 \%}$ groups in comparison to the $\mathrm{M}_{0}$ group. These findings disclose that supplementing the diet with 3.5\% MOLP improves antioxidant status, milk yield, and reproductive performance in goats.

Keywords: Moringa oleifera, plasma biochemistry, antioxidant status, milk composition, productive performance, goat 


\section{INTRODUCTION}

Reproductive performance is a key factor in goat production and is directly related to maternal nutrition. The pariparturient period (late gestation and early lactation) is characterized by depressed feed intake, endocrine, and metabolic changes that interrupt energy balance and anti-oxidant status of the body $(1,2)$. Nutritional requirements are high during this period due to accelerated digestion rate, tissue mobilization for mammary development, and fetus growth (3). However, maternal malnutrition is common in small ruminants in most parts of the world due to scarcity and high cost of feed stuffs. The farmers, in these regions, mostly depend on conventional grazing and crop residues to meet the requirements of their animals. The natural grazing pastures and crop residues have fluctuating nutritional status, and their feeding alone is not sufficient to satisfy the energy needs of pregnant and lactating animals (4). The energy deficit feed makes the pregnant animals more prone to oxidative stress with enormous production of reactive oxygen species (ROS) that results in a disturbance of the balance between oxidant and antioxidant defense systems of the body (5). All biomolecules including lipids, carbohydrates, and proteins are adversely affected by oxidative stress, which ultimately leads to a decline in reproductive and productive performance (6). Furthermore, the newborn kids may suffer from a variety of diseases that will negatively influence their survival and growth rate (7).

Colostrum is the first secretion produced soon after parturition and is a source of immunity for newborns. Immunoglobulins, minerals, and many other biologically active substances are transferred passively through the colostrum to the kids of sheep, goat, cattle, and horse as they do not get into the embryo's bloodstream (8). The composition and quality of colostrum and milk predominantly depend on the nutrition of the mother $(9,10)$. The feed should fulfill the nutritional requirements of pregnant animals to get good quality of colostrum and milk from them after parturition. The inadequate supply of nutrients will adversely affect the synthesis and composition of colostrum and milk.

The diet manipulation with phytobiotics (plant-derived feed additives) has been proposed to be an effective approach in managing nutrition-induced oxidative stress during pregnancy and lactation in both small and large ruminants (11-14). Some herbal plants have medicinal values and are nutritionally important to enhance the health status and reproductive performance of goats. Their supplementation with a basal diet can minimize nutrition-related problems in goat production (15).

Moringa oleifera (MO) is an evergreen tree fodder, also known as a "miracle tree," and is one of the most useful, multi-purpose, fast-growing, and drought-resistant trees. It is well-known for its medicinal importance and nutritional characteristics. Moringa leaves contain a sufficient quantity of vitamins, minerals, and proteins according to the nutritional demands of pregnant and lactating animals $(16,17)$. Moreover, $\mathrm{MO}$ leaves are also a rich source of different bioactive compounds, especially abundant in antioxidants including flavonoids (kaempferol, myricetin, and quercetin), phenolic acids (gallic, ellagic, and chlorogenic acid), Vit C, Vit E, $\beta$-carotene, Se, and Zn (18). These substances have been detected separately in various plants, but $\mathrm{MO}$ is distinct in having them all in substantial amounts (19).

The MO leaves are readily adapted and easily digested by animals. The favorable impacts of MO have been observed on the anti-oxidant status and reproductive performance in mice and sows $(20,21)$. However, there is little information about dietary supplementation effects of Moringa oleifera leaf powder (MOLP) during the nutritionally critical stages (late pregnancy and early lactation) in goats. Therefore, the study was designed to evaluate the effects of MOLP as a nutritional supplement on productive and reproductive performance, plasma, and milk biochemical indices in Beetal goats. The results of this study will enlighten the knowledge about the development of different bioactive compounds from MO leaf in the field of goat reproduction.

\section{MATERIALS AND METHODS}

\section{Ethical Statement}

The procedures used for study and ethical clearance were approved and granted by Animal Use and Care Research Committee at Nuclear Institute for Agriculture and Biology (NIAB), Faisalabad, Pakistan.

\section{Experimental Design and Animal Husbandry}

The experiment was conducted at the goat research farm of Nuclear Institute for Agriculture and Biology (NIAB), situated $\sim 7 \mathrm{~km}$ from the nucleus of the city Faisalabad, Pakistan (longitude $73.0791^{\circ} \mathrm{E}$ and latitude $31.4287^{\circ} \mathrm{N}$ ) at an altitude of $184 \mathrm{~m}$ from sea level. The average rainfall and temperature were $15.50 \mathrm{~mm}$ and $41^{\circ} \mathrm{C}$ during the months (April to July 2020) of the experiment.

A total of 30 pregnant Beetal goats of 2-3 years age and weighing about $40 \mathrm{~kg} \pm 2.3$ were selected exactly 2 months before their predicted delivery. The ultrasonographic examination of goats was performed by the Department of Theriogenology, University of Agriculture, Faisalabad for confirmation of pregnancy. All the goats were randomly divided $(n=10)$ into the control $\left(\mathrm{M}_{0}\right)$ group (250 g basal diet without MOLP/animal/day), $\mathrm{M}_{2 \%}$ group (250 $\mathrm{g}$ basal diet with $5 \mathrm{~g} \mathrm{MOLP} / \mathrm{animal} /$ day), and $\mathrm{M}_{3.5 \%}$ group (250 g basal diet with $8.75 \mathrm{~g} \mathrm{MOLP} / \mathrm{animal} /$ day). The basal diet was composed of wheat, corn, rice bran, sugarcane molasses, minerals, and soybean meal formulated according to the nutritional requirements of pregnant goats (Table 1) (23). The experiment was initiated 2 months before the estimated due date of kidding and continued till the first month of lactation. All the animals were acclimatized 1 week for the basal diet. Before the start of the experiment, deworming was performed with Albendazole (Zoben, Prix, Lahore, Pakistan) at a dose rate of $2.5 \mathrm{mg} / 5 \mathrm{~kg} / \mathrm{BW}$. The goats were kept in well-ventilated semiopen sheds and offered two times free pasture grazing (Chloris gayana, Leptochloa fusca, Carduus nutans, Chenopodium album, and Cirsium arvense) during morning and evening schedule with free access to clean drinking water. 
TABLE 1 | Formulation of basal diet (\% DM).

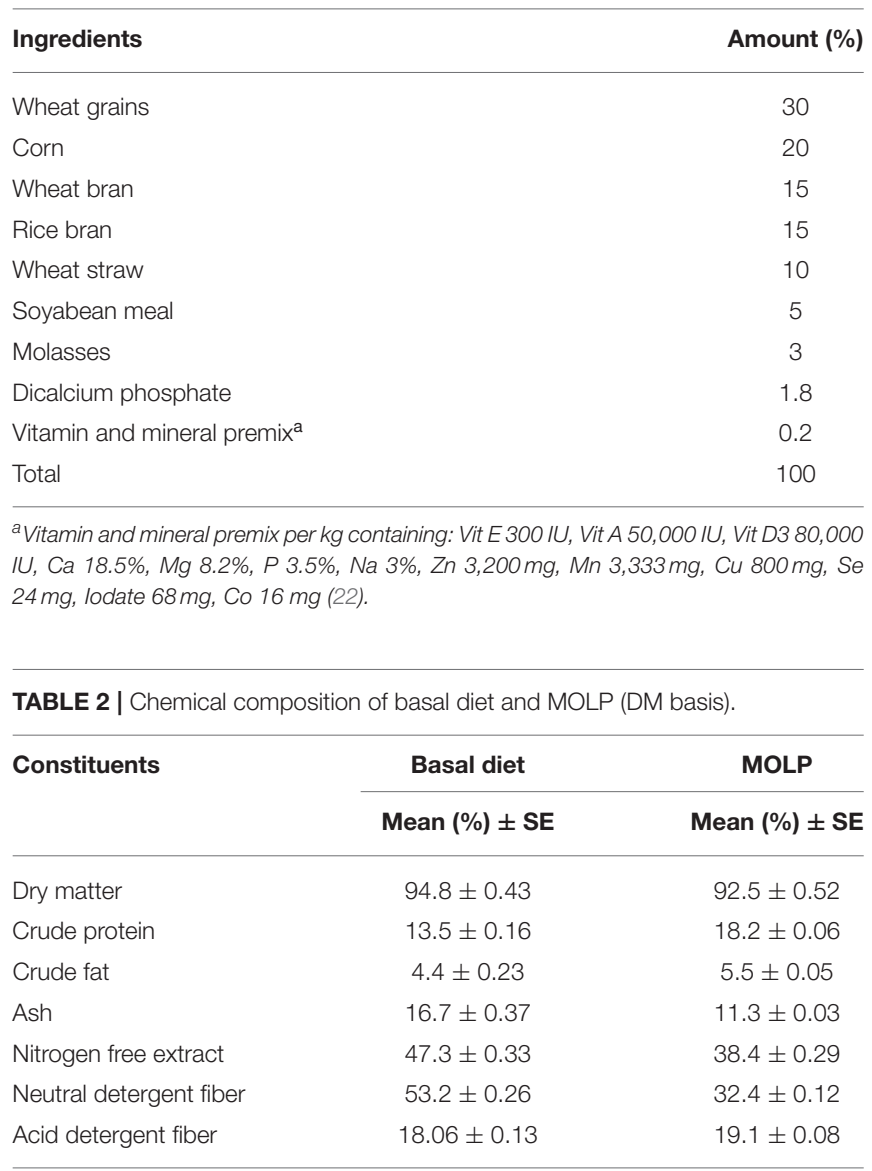

MOLP, Moringa oleifera dried leaf powder (22).

\section{Plant Material}

The fresh green leaves of MO (PKM1) were collected from a breeder's farm (Lahore, Pakistan) during the month of November 2019, and their authenticity was assured by an experienced botanist at NIAB. A representative sample of leaves was sent to the institute's herbarium for reference in the future. The leaves were cleaned properly by washing and dried under shade at room temperature for 4 days. The dried leaves were processed to make powder and then stored in airtight containers for use in the experiment.

\section{Compositional Analysis of Diet}

The MOLP and basal diet were subjected to proximate chemical compositional analysis by using standardized methods of analytical chemists (24) as also used in our previous study (22). The MOLP was also analyzed for its different biochemical elements spectrophotometrically (UV-VIS U2800, Hitachi, Japan). The compositional analysis of MOLP and basal diet are presented in Tables 2, 3 .

\section{Collection of Blood and Milk Samples}

Blood samples $(5 \mathrm{ml})$ were collected in sterile EDTA tubes (Vacutainer, Xinle) from the jugular vein with 20-day intervals
TABLE 3 | Nutritional constituent analysis of MOLP.

\begin{tabular}{lc}
\hline Biochemical constituents & Mean \pm SE \\
\hline Total phenolic contents $(\mu \mathrm{M} / \mathrm{g})$ & $36,000 \pm 3.21$ \\
Total Flavonoids $(\mu \mathrm{g} / \mathrm{g})$ & $258.58 \pm 2.28$ \\
Vitamin C $(\mu \mathrm{g} / \mathrm{g})$ & $546.16 \pm 3.06$ \\
Lycopene $(\mathrm{mg} / \mathrm{g})$ & $9.95 \pm 0.17$ \\
Total carotenoids $(\mathrm{mg} / \mathrm{g})$ & $13.87 \pm 0.33$ \\
Total sugars $(\mathrm{mg} / \mathrm{g})$ & $27.51 \pm 1.52$ \\
Methionine $(\%$ of DM) & $0.42 \pm 0.012$ \\
Cysteine $(\%$ of DM) & $0.52 \pm 0.014$ \\
Sodium $(\mathrm{mg} / \mathrm{g})$ & $2.13 \pm 0.075$ \\
Calcium $(\mathrm{mg} / \mathrm{g})$ & $180 \pm 1.154$ \\
Potassium $(\mathrm{mg} / \mathrm{g})$ & $8.99 \pm 0.571$ \\
Selenium $(\mathrm{mg} / \mathrm{g})$ & $0.31 \pm 0.057$ \\
Iron $(\mathrm{mg} / \mathrm{g})$ & $0.16 \pm 0.034$
\end{tabular}

MOLP, Moringa oleifera leaf powder (22).

after the start of the experimental diet from day 90 of gestation. Plasma was separated from blood samples by centrifugation at $3,000 \mathrm{rpm} / 4^{\circ} \mathrm{C}$ and stored at $-20^{\circ} \mathrm{C}$ till further analysis. Colostrum samples were obtained within $2 \mathrm{~h}$ after parturition. Milk samples were collected with 1-week interval for 4 consecutive weeks and stored at $-20^{\circ} \mathrm{C}$ for further biochemical analyses. Blood and milk samples were collected at 7-8 a.m. during the whole experiment. The defatting of colostrum and milk samples was done by centrifugation at 2,500 $\times g$ for $15 \mathrm{~min}$ for enzymatic and non-enzymatic antioxidant estimation.

\section{Analysis of Blood Plasma Non-enzymatic Antioxidants Total Flavonoids}

Total flavonoids (TF) in plasma samples were estimated by $\mathrm{AlCl}_{3}$ colorimetric assay and rutin was used as standard (25). The samples were mixed with $100 \mu \mathrm{l}$ of $10 \% \mathrm{AlCl}_{3}, 100 \mu \mathrm{l}$ of $1 \mathrm{M}$ potassium acetate, and $275 \mu \mathrm{l}$ of deionized water. The contents were incubated for $40 \mathrm{~min}$ at room temperature and then absorbance was measured at $415 \mathrm{~nm}$ by using a double beam spectrophotometer (UV-VIS U2800, Hitachi, Japan). The TFs were computed with the help of a standard curve and expressed as $\mu \mathrm{g}$ RE (retinol equivalents) per milliliter of sample.

\section{Total Phenolic Content}

Total phenolic contents (TPC) were assessed using a modified Folin-Ciocalteu procedure (26). The $100-\mu 1$ blood plasma sample was vortexed with $100 \mu \mathrm{l}$ of Folin-Ciocalteu reagent for $15 \mathrm{~s}$ and then incubated for $1 \mathrm{~h}$ at room temperature after adding $700 \mathrm{mM}$ $\mathrm{Na}_{2} \mathrm{CO}_{3}(800 \mu \mathrm{l})$. The absorbance of reaction was read at $765 \mathrm{~nm}$ and TPCs were calculated from a linear regression equation.

\section{Vitamin C}

Vitamin $\mathrm{C}$ was determined by using a standardized protocol of Moeslinger et al. (27). Briefly, vitamin C causes reduction of a colored compound 2,6 Dichlorophenolindophenol (DCPIP) into $\mathrm{DCPIPH}_{2}$ (colorless compound). This reaction was monitored 
by fall-off absorbance at $520 \mathrm{~nm}$. The concentration of vitamin $\mathrm{C}$ in plasma samples was measured by using a standard calibration curve.

\section{Malondialdehyde}

Malondialdehyde (MDA) concentration in blood plasma samples was assessed colorimetrically by using MDA as standard (28). Plasma sample $(25 \mu \mathrm{l})$ was homogenized in $0.1 \%$ trichloroacetic acid and centrifuged exactly for $5 \mathrm{~min}$ at $14,000 \times g$. Then, trichloroacetic acid (20\%) containing thiobarbituric acid (0.05\%) was added in $1 \mathrm{ml}$ aliquot of the supernatants and heated for $30 \mathrm{~min}$ by placing in boiling water bath. The reaction mixture was cooled after removing from the water bath and centrifuged for $10 \mathrm{~min}$ at $14,000 \times \mathrm{g}$. The absorbance of clear supernatants was read at $535 \mathrm{~nm}$ and the value of non-specific absorbance $(600 \mathrm{~nm})$ was subtracted from it. The MDA contents were measured by a coefficient of extinction 155 per $\mathrm{mM}$ per $\mathrm{cm}$.

\section{Total Antioxidant Capacity}

Total antioxidant capacity (TAC) of plasma samples was measured by an assay based on the reduction of a blue radical cation $\left(\mathrm{ABTS}^{\bullet+}\right)$ to its original ABTS colorless form by antioxidants (29). The assay solution to measure TAC is composed of reagent $\mathrm{R}_{1}$ ( $\mathrm{CH} 3 \mathrm{COONa}$ buffer and glacial acetic acid), $\mathrm{R}_{2}\left(\mathrm{H}_{2} \mathrm{O}_{2}, \mathrm{Na} 3 \mathrm{PO} 4\right.$ buffer, glacial acetic acid, and ABTS), and sample. The contents of the reaction solution were incubated for about $6 \mathrm{~min}$ at room temperature and then absorbance was read at $660 \mathrm{~nm}$. The TAC value was computed from a standard ascorbic acid calibration curve and represented as ascorbic acid $(\mu \mathrm{M})$ equivalent per milliliter of sample.

\section{Total Oxidant Status}

The method for the determination of total oxidant status (TOS) values of plasma samples is based on the oxidation of $\mathrm{Fe}^{2+}$ into $\mathrm{Fe}^{3+}$ by oxidants present in the sample (29). A specific color appeared when $\mathrm{Fe}^{3+}$ ions react with xylenol and the magnitude of color is directly related to the quantity of oxidant molecules that were measured spectrophotometrically. The reaction solution for the determination of TOS value is composed of $\mathrm{R}_{1}$, xylenol solution $\left(0.38 \mathrm{~g}\right.$ in $500 \mu \mathrm{l}$ of $\left.25 \mathrm{mM} \mathrm{H}_{2} \mathrm{SO}_{4}\right), \mathrm{R}_{2}$ [ferrous ammonium sulfate (II) $0.0196 \mathrm{~g}$, o-dianisidine $0.0317 \mathrm{~g}$, glycerol $500 \mu \mathrm{l}$, and $\mathrm{NaCl} 0.4 \mathrm{~g}$ ], and sample. The absorbance value was read after 5 min of adding $\mathrm{R}_{2}$. Hydrogen peroxide $\left(\mathrm{H}_{2} \mathrm{O}_{2}\right)$ was used to calculate the final value of TOS that was expressed in $\mu \mathrm{M}$ $\mathrm{H}_{2} \mathrm{O}_{2}$ equivalent per milliliter.

\section{Enzymatic Antioxidants \\ Superoxide Dismutase Activity}

The plasma samples were assayed for superoxide dismutase (SOD) activity by an inhibition assay that works on the base of SOD ability to inhibit the photochemical reduction of nitroblue tetrazolium (NBT) into formazan (30). The reaction solution for the study of inhibition assay is composed of $50 \mathrm{mM}$ potassium phosphate buffer ( $\mathrm{pH} 7.8$ ), $13 \mathrm{mM}$ L-methionine, $57 \mu \mathrm{M} \mathrm{NBT}$, Triton X-100 (0.025\%), riboflavin $(0.004 \%)$, and $50 \mu \mathrm{l}$ of blood plasma sample in a total volume of $3 \mathrm{ml}$. The photoreaction was performed in a box lined with aluminum (Al) foil and having a
15-W lamp as a light source. The absorbance of the reduction reaction of NBT to formazan was taken at $560 \mathrm{~nm}$ and a unit of SOD activity was defined as the amount of enzyme required to cause $50 \%$ inhibition of NBT.

\section{Peroxidase Activity}

Plasma peroxidase (POD) activity was estimated by using the method of Agostini et al. (31) with some necessary modifications and using guaiacol as substrate. The assay solution to measure POD activity contained guaiacol $(200 \mathrm{mM}), \mathrm{H}_{2} \mathrm{O}_{2}(400 \mathrm{mM})$, $545 \mu \mathrm{l}$ of distilled water, $200 \mathrm{mM}$ potassium phosphate buffer ( $\mathrm{pH} 7.0$ ), and $15 \mu \mathrm{l}$ of blood plasma sample. The reaction was initiated immediately after the addition of the plasma sample, and the absorbance of the reaction solution was measured after every $20 \mathrm{~s}$ for $1 \mathrm{~min}$ at $470 \mathrm{~nm}$. One unit of POD activity was narrated as the quantity of enzyme that catalyzed the oxidation of guaiacol.

\section{Catalase Activity}

Catalase (CAT) activity of blood plasma samples was measured by mixing the samples with $50 \mathrm{mM}$ potassium phosphate buffer $(\mathrm{pH} 7.0)$ and dithiothreitol $(1 \mathrm{mM})$ as described by Beers and Sizer (32). The reaction mixture to study CAT activity contained $59 \mathrm{mM} \mathrm{H} \mathrm{H}_{2} \mathrm{O}_{2}, 50 \mathrm{mM}$ phosphate buffer ( $\mathrm{pH} \mathrm{7)}$, and a 100- $\mu \mathrm{l}$ plasma sample. The decreasing pattern of absorbance was measured after every $20 \mathrm{~s}$ for $1 \mathrm{~min}$ at $240 \mathrm{~nm}$ and a unit of CAT activity was described as a change in absorbance in $0.01 \mathrm{~min}$.

\section{Biochemical Parameters \\ Total Soluble Protein}

The quantitative protein estimation of plasma samples was performed by dye-binding method as described by Bradford (33). The plasma sample $(5 \mu \mathrm{l})$ was mixed and homogenized with $0.1 \mathrm{~N} \mathrm{NaCl}$. The reaction solution was incubated for $5 \mathrm{~min}$ at room temperature after adding $1 \mathrm{ml}$ Bradford dye to form a protein-dye complex. Thereafter, absorbance was measured at $420 \mathrm{~nm}$.

\section{Total Sugar}

The total sugar level of plasma samples was enacted by Folin's (34) protocol with few desired modifications. Briefly, the samples were mixed with sulfuric acid $\left(\mathrm{H}_{2} \mathrm{SO}_{4}\right)$ and neutralized by using sodium carbonate $\left(\mathrm{Na}_{2} \mathrm{CO}_{3}\right)$. The contents were then filtered and absorbance was read spectrophotometrically at $415 \mathrm{~nm}$ for estimation of sugar contents.

\section{Lycopene and Carotenoids}

Lycopene and carotenoids in blood plasma samples were assayed according to the standardized procedure of Nagata and Yamashita (35). For estimation of lycopene and carotenoids, $1 \mathrm{ml}$ of blood plasma sample was thoroughly homogenized with $10 \mathrm{ml}$ of hexane and acetone solution (6:4). The assay solution was incubated for $5 \mathrm{~min}$ at $37^{\circ} \mathrm{C}$ and then filtered. The absorbance was measured at 453,505, and $663 \mathrm{~nm}$, and finally the quantities of lycopene and carotenoids were calculated with the help of the following formulae:

$$
\begin{aligned}
& \text { Lycopene }=-0.0458 \mathrm{~A}_{663}+0.372 \mathrm{~A}_{505} \\
& \text { Carotenoids }=0.216 \mathrm{~A}_{663}-0.304 \mathrm{~A}_{505}+0.452 \mathrm{~A}_{453}
\end{aligned}
$$




\section{Hydrolytic Enzymes \\ Protease}

The protease activity was measured by the casein digestion method (36). Protease enzyme releases an amino acid "tyrosine" after digestion of casein. The reaction of tyrosine Folin's reagent results in the formation of a blue color product that is quantified at $660 \mathrm{~nm}$. A standard calibration curve of tyrosine was used to compute the protease activity in plasma samples. One unit of enzyme activity was defined as the amount of enzyme that causes the release of soluble acid fragments equivalent to 0.001 A $280 \mathrm{~nm}$ in $1 \mathrm{~min}$ at $\mathrm{pH} 7.8$.

\section{Esterase}

The esterase (alpha and beta) enzyme activity was estimated by utilizing naphthyl acetate ( $\alpha$ and $\beta$ ) as substrate as described by Van Asperen (37). The reaction mixture consisting of plasma (enzyme extract), phosphate buffer (0.04 M, pH 7), $30 \mathrm{mM}$ naphthyl acetate $(\alpha$ and $\beta$ ), and $1 \%$ acetone was incubated in the dark at $37^{\circ} \mathrm{C}$ for $15 \mathrm{~min}$. Then, $1 \mathrm{ml}$ of staining solution composed of fast blue BB (1\%) and sodium dodecyl sulfate (5\%) was added in both blank control (phosphate buffer and substrate solution) and reaction mixture and again incubated for $15 \mathrm{~min}$ in the dark at room temperature. The absorbance of the assay was recorded at $590 \mathrm{~nm}$, and the enzyme activity was calculated in $\mu \mathrm{M} \mathrm{min}{ }^{-1} \mathrm{ml}^{-1}$ of a sample using a standard curve.

\section{Amylase}

The activity of the amylase enzyme in plasma samples was assessed by using $0.2 \mathrm{M}$ tris-malate $(\mathrm{pH} 7.2)$ buffer as an extraction cum assay medium (38). For estimation of enzyme activity, $1 \mathrm{ml}$ of substrate solution $(0.15 \%$ starch) was homogenized with $1 \mathrm{ml}$ of plasma and incubated at $37^{\circ} \mathrm{C}$ for $10 \mathrm{~min}$. The OD of the reaction mixture was measured at $620 \mathrm{~nm}$ after adding quenching reagent and enzyme activity was represented in milligrams of starch degraded per minute per milliliter of blood plasma sample.

\section{Analysis of Milk}

Milk samples were analyzed for chemical composition by a milk analyzer (Julie Z7, Scope Electric, Regensburg, Germany). The defatted milk samples were used for estimation of non-enzymatic (TPC, TAC, and vitamin C) and enzymatic (SOD, POD, and CAT) antioxidants by a spectrophotometer (UV-VIS U2800, Hitachi, Japan) as described above for plasma samples.

\section{Reproductive and Productive Performance}

The reproductive and productive performance was evaluated in terms of birth weight, weight gain per week, survival rate of newly born kids, shedding time of placenta, the onset of first postpartum estrus, and milk yield in goats.

\section{Statistical Analysis}

All the statistical analyses were carried out by using SPSS version 20. The experimental procedures were performed in triplicate, and data obtained were analyzed by one-way analysis of variance (ANOVA) with repeated measures under the shade of LSD to access the differences among different treatment means on specific days. The results were expressed in the tables as mean $\pm \mathrm{SE}$, and the values with $p<0.05$ were considered statistically significant.

\section{RESULTS}

\section{Non-enzymatic Antioxidant Parameters}

The response of plasma non-enzymatic antioxidant parameters to MOLP supplementation during pregnancy and early lactation period is shown in Table 4. Plasma TFs were increased significantly from day 110 of pregnancy to day 20 of lactation in the $\mathrm{M}_{3.5 \%}$ group $(p<0.05)$. The impact of supplementation was non-significant on $\mathrm{M}_{2} \%$ group plasma TFs as compared to the control $\left(\mathrm{M}_{0}\right)$ group $(p>0.05)$. The values of plasma TPC of the $\mathrm{M}_{3.5 \%}$ and $\mathrm{M}_{2 \%}$ groups were non-significant in the pregnancy stage, while they became significant during the early lactation period of the experiment $(p<0.05)$. The increase in plasma Vit $C$ contents was significant $(p<0.05)$ from the 130th day of pregnancy till day 20 of lactation in both $\mathrm{M}_{3.5 \%}$ and $\mathrm{M}_{2 \%}$ supplemented groups. The MOLP supplementation significantly improved the plasma TAC by declining MDA concentration and TOS values near parturition and early lactation stage of the experiment in contrast to the control $\left(\mathrm{M}_{0}\right)$ group $(p<0.05)$.

\section{Enzymatic Antioxidants}

The MOLP supplementation impacts on plasma enzymatic antioxidants are presented in Table 5. The SOD activity of $\mathrm{M}_{3.5 \%}$ and $\mathrm{M}_{2 \%}$ groups increased significantly throughout the experiment in response to supplementation $(p<0.05)$ and reached its peak on day 20 of lactation in the $M_{3.5 \%}$ group. The effect of supplementation levels (3.5 and 2\%) was non-significant on POD activity $(p>0.05)$. However, there was a significant difference between the POD activities of supplemented $\left(\mathrm{M}_{3.5 \%}\right.$ and $\left.\mathrm{M}_{2 \%}\right)$ and control $\left(\mathrm{M}_{0}\right)$ groups during the entire experiment $(p<0.05)$. A non-significant increase in the plasma CAT activity was noticed till day 150 of gestation $(p>0.05)$, but soon after kidding, the CAT activity was enhanced significantly during the lactation period according to the supplementation levels in $\mathrm{M}_{3.5 \%}$ and $\mathrm{M}_{2 \%}$ groups as compared to the control $\left(\mathrm{M}_{0}\right)$ group $(p<0.05)$.

\section{Biochemical Indices}

The change in plasma biochemical indicators in response to MOLP supplementation is given in Table 6. The supplementation initially showed no pronounced effect on plasma TSP contents till the 130th day of pregnancy. Thereafter, the plasma TSP contents increased significantly on day 150 of pregnancy and day 20 of lactation in $\mathrm{M}_{3.5 \%}$ group in comparison to $\mathrm{M}_{2} \%$ and $\mathrm{M}_{0}$ groups $(p<0.05)$. The plasma sugar level of both $\mathrm{M}_{3.5 \%}$ and $\mathrm{M}_{2 \%}$ supplemented groups increased significantly from the beginning of the experiment till day 20 of lactation ( $p$ $<0.05)$. A drastic increase in plasma sugar level was observed soon after kidding in supplemented groups in contrast to the control group. The concentration of carotenoids in plasma was significantly enhanced throughout the experiment in the $\mathrm{M}_{3.5 \%}$ group as compared to the control $\left(\mathrm{M}_{0}\right)$ group $(p<0.05)$, whereas the lycopene contents were improved from day 130 of 
TABLE 4 | Plasma non-enzymatic antioxidant indices of Beetal goats.

\begin{tabular}{|c|c|c|c|c|c|}
\hline \multirow[t]{2}{*}{ Non-enzymatic antioxidants } & \multicolumn{3}{|c|}{ Levels of Moringa oleifera leaf powder supplementation } & \multirow[t]{2}{*}{ SEM } & \multirow[t]{2}{*}{$p$-value } \\
\hline & $\mathbf{M}_{0}$ & $\mathbf{M}_{\mathbf{2} \%}$ & $\mathbf{M}_{3.5 \%}$ & & \\
\hline \multicolumn{6}{|l|}{ Gestation day 110} \\
\hline Total flavonoids ( $\mu \mathrm{g} / \mathrm{ml})$ & $239.93 \pm 0.91^{b}$ & $241.06 \pm 0.74^{b}$ & $253.91 \pm 0.72^{\mathrm{a}}$ & 0.43 & 0.030 \\
\hline Total phenolic contents ( $\mu \mathrm{M} / \mathrm{ml})$ & $5,821.75 \pm 0.85^{b}$ & $5,832.61 \pm 1.60^{\mathrm{a}}$ & $5840 \pm 2.45^{\mathrm{a}}$ & 1.19 & 0.028 \\
\hline Vitamin C $(\mu \mathrm{g} / \mathrm{ml})$ & $803.75 \pm 1.55$ & $805.50 \pm 1.04$ & $810.25 \pm 1.44$ & 0.84 & 0.221 \\
\hline Malondialdehyde $(\mu \mathrm{M} / \mathrm{ml})$ & $5.90 \pm 0.33$ & $5.76 \pm 0.37$ & $5.59 \pm 0.26$ & 0.17 & 0.627 \\
\hline Total anti-oxidant capacity $(\mu \mathrm{M} / \mathrm{ml})$ & $1.41 \pm 0.02^{\mathrm{c}}$ & $1.55 \pm 0.01^{\mathrm{b}}$ & $1.67 \pm 0.01^{a}$ & 0.01 & 0.002 \\
\hline Total oxidant status ( $\mu \mathrm{M} / \mathrm{ml})$ & $1,566.25 \pm 1.11$ & $1,559.75 \pm 0.63$ & $1,555.50 \pm 2.10$ & 1.04 & 0.065 \\
\hline \multicolumn{6}{|l|}{ Gestation day 130} \\
\hline Total flavonoids ( $\mu \mathrm{g} / \mathrm{ml})$ & $251.31 \pm 0.59^{b}$ & $256.14 \pm 0.76^{b}$ & $272.79 \pm 1.07^{a}$ & 0.29 & 0.013 \\
\hline Total phenolic contents $(\mu \mathrm{M} / \mathrm{ml})$ & $5,819 \pm 0.82^{b}$ & $5,844.75 \pm 1.31^{\mathrm{a}}$ & $5,848.25 \pm 0.95^{a}$ & 0.65 & 0.007 \\
\hline Vitamin C ( $\mu \mathrm{g} / \mathrm{ml})$ & $795 \pm 1.08^{c}$ & $811.25 \pm 1.32^{b}$ & $819.50 \pm 0.96^{a}$ & 0.42 & 0.008 \\
\hline Malondialdehyde ( $\mu \mathrm{M} / \mathrm{ml})$ & $7.26 \pm 0.09^{b}$ & $5.28 \pm 0.23^{a}$ & $5.06 \pm 0.27^{a}$ & 0.18 & 0.024 \\
\hline Total anti-oxidant capacity $(\mu \mathrm{M} / \mathrm{ml})$ & $1.49 \pm 0.01^{\mathrm{c}}$ & $1.73 \pm 0.02^{b}$ & $1.86 \pm 0.02^{\mathrm{a}}$ & 0.01 & 0.002 \\
\hline Total oxidant status ( $\mu \mathrm{M} / \mathrm{ml})$ & $1,585.25 \pm 0.63^{c}$ & $1,533 \pm 0.71^{b}$ & $1,502.5 \pm 0.96^{a}$ & 0.39 & $<0.001$ \\
\hline \multicolumn{6}{|l|}{ Gestation day 150} \\
\hline Total flavonoids ( $\mu \mathrm{g} / \mathrm{ml})$ & $258.93 \pm 1.13^{b}$ & $264.66 \pm 0.68^{b}$ & $278.84 \pm 0.58^{a}$ & 0.67 & 0.001 \\
\hline Total phenolic contents $(\mu \mathrm{M} / \mathrm{ml})$ & $5,796.50 \pm 0.86^{b}$ & $5,853 \pm 0.57^{a}$ & $5,859.25 \pm 2.05^{\mathrm{a}}$ & 1.14 & $<0.001$ \\
\hline Vitamin C ( $\mu \mathrm{g} / \mathrm{ml})$ & $780 \pm 0.41^{c}$ & $816.75 \pm 0.85^{b}$ & $827.75 \pm 0.48^{a}$ & 0.39 & $<0.001$ \\
\hline Malondialdehyde ( $\mu \mathrm{M} / \mathrm{ml})$ & $8.31 \pm 0.12^{b}$ & $4.55 \pm 0.22^{a}$ & $4.19 \pm 0.18^{a}$ & 0.06 & 0.004 \\
\hline Total anti-oxidant capacity $(\mu \mathrm{M} / \mathrm{ml})$ & $1.37 \pm 0.02^{c}$ & $1.81 \pm 0.01^{b}$ & $1.96 \pm 0.04^{a}$ & 0.02 & 0.007 \\
\hline Total oxidant status ( $\mu \mathrm{M} / \mathrm{ml})$ & $1,605 \pm 1.08^{c}$ & $1,515.75 \pm 0.85^{b}$ & $1,481 \pm 0.82^{\mathrm{a}}$ & 0.86 & $<0.001$ \\
\hline \multicolumn{6}{|l|}{ Lactation day 20} \\
\hline Total flavonoids ( $\mu \mathrm{g} / \mathrm{ml})$ & $265.28 \pm 1.23^{b}$ & $273.19 \pm 2.46^{b}$ & $291.44 \pm 0.63^{a}$ & 1.06 & 0.013 \\
\hline Total phenolic contents $(\mu \mathrm{M} / \mathrm{ml})$ & $5,811.50 \pm 0.64^{c}$ & $5,866 \pm 0.71^{\mathrm{b}}$ & $5,884 \pm 1.08^{a}$ & 0.68 & $<0.001$ \\
\hline Vitamin C $(\mu \mathrm{g} / \mathrm{ml})$ & $783 \pm 0.39^{c}$ & $825.51 \pm 0.48^{b}$ & $838.69 \pm 1.25^{\mathrm{a}}$ & 0.44 & $<0.001$ \\
\hline Malondialdehyde ( $\mu \mathrm{M} / \mathrm{ml})$ & $7.94 \pm 0.25^{\mathrm{c}}$ & $4.01 \pm 0.04^{b}$ & $2.74 \pm 0.29^{a}$ & 0.11 & 0.013 \\
\hline Total anti-oxidant capacity $(\mu \mathrm{M} / \mathrm{ml})$ & $1.53 \pm 0.01^{\mathrm{c}}$ & $1.94 \pm 0.01^{b}$ & $2.16 \pm 0.04^{a}$ & 0.02 & 0.001 \\
\hline Total oxidant status ( $\mu \mathrm{M} / \mathrm{ml})$ & $1,598.50 \pm 0.65^{c}$ & $1,492.50 \pm 1.04^{b}$ & $1,459.75 \pm 0.48^{a}$ & 0.42 & $<0.001$ \\
\hline
\end{tabular}

Means with superscript letters $(a, b, c)$ within the same row differ significantly at $p \leq 0.05$.

pregnancy to day 20 of lactation in the $\mathrm{M}_{3.5 \%}$ as well as $\mathrm{M}_{2} \%$ group $(p<0.05)$.

\section{Hydrolytic Enzymes}

The activities of plasma hydrolytic enzymes in supplemented $\left(\mathrm{M}_{3.5 \%}\right.$ and $\left.\mathrm{M}_{2 \%}\right)$ and control $\left(\mathrm{M}_{0}\right)$ groups are illustrated in Table 7. The protease enzyme activity was modified more effectively from day 130 to 150 of gestation in the $\mathrm{M}_{3.5 \%}$ group in comparison to the $\mathrm{M}_{2} \%$ group. However, the supplementation of MOLP significantly influenced plasma protease activity in the $\mathrm{M}_{2 \%}$ group during the lactation period $(p<0.05)$. However, the supplementation did not show any significant impact on esterase activity during the experiment $(p>0.05)$. The amylase activity was slightly improved in the $\mathrm{M}_{3.5 \%}$ group from day 150 of gestation in comparison to the control $\left(\mathrm{M}_{0}\right)$ group $(p<0.05)$.

\section{Milk Biochemical Composition}

The alterations in milk biochemical composition as a result of MOLP supplementation are expressed in Table 8. The colostrum and milk protein contents were increased significantly in
$\mathrm{M}_{3.5 \%}$ group. However, the supplementation in the $\mathrm{M}_{2 \%}$ group exhibited a significant impact on days 21 and 28 milk protein contents $(p<0.05)$. The milk fat percentage was not affected by supplementation in either the $M_{3.5 \%}$ or $M_{2} \%$ group up to day 14 of lactation $(p>0.05)$, but on days 21 and 28, the milk fat was significantly increased in the $\mathrm{M}_{3.5 \%}$ group as compared to the control $\left(\mathrm{M}_{0}\right)$ group $(p<0.05)$. There was no influence of supplementation on the lactose contents of colostrum and mature milk samples of $\mathrm{M}_{3.5 \%}$ and $\mathrm{M}_{2} \%$ groups $(p>0.05)$. Total carotenoids were significantly high in the milk samples of the $\mathrm{M}_{3.5 \%}$ group as compared to $\mathrm{M}_{2} \%$ and $\mathrm{M}_{0}$ groups from day 0 to day 28 of lactation $(p<0.05)$.

\section{Milk Enzymatic and Non-enzymatic Antioxidants}

The enzymatic and non-enzymatic antioxidant parameters of the colostrum and milk samples are presented in Table 9. The TPCs in the colostrum and milk samples of the $\mathrm{M}_{3.5 \%}$ group were significantly increased in response to supplementation. There was no effect of supplementation on the TPCs of colostrum from 
TABLE 5 | Plasma enzymatic antioxidant indices of Beetal goats.

\begin{tabular}{|c|c|c|c|c|c|}
\hline \multirow[t]{2}{*}{ Enzymatic antioxidants (Units/ml) } & \multicolumn{3}{|c|}{ Levels of Moringa oleifera leaf powder supplementation } & \multirow[t]{2}{*}{ SEM } & \multirow[t]{2}{*}{$p$-value } \\
\hline & $\mathbf{M}_{0}$ & $\mathbf{M}_{2 \%}$ & $\mathbf{M}_{3.5 \%}$ & & \\
\hline \multicolumn{6}{|l|}{ Gestation day 110} \\
\hline SOD & $21.29 \pm 0.52^{\mathrm{c}}$ & $25.82 \pm 0.28^{b}$ & $32.08 \pm 0.39^{a}$ & 0.23 & 0.011 \\
\hline POD & $195.82 \pm 0.61^{b}$ & $207.16 \pm 0.79^{a}$ & $212.24 \pm 1.30^{\mathrm{a}}$ & 0.45 & 0.002 \\
\hline CAT & $40 \pm 0.82$ & $41 \pm 1.29$ & $44.75 \pm 0.48$ & 0.52 & 0.062 \\
\hline \multicolumn{6}{|l|}{ Gestation day 130} \\
\hline SOD & $19.88 \pm 0.63^{c}$ & $28.20 \pm 0.57^{b}$ & $37.77 \pm 0.73^{a}$ & 0.29 & 0.015 \\
\hline POD & $209.65 \pm 0.88^{b}$ & $231.79 \pm 1.16^{\mathrm{a}}$ & $238.17 \pm 1.06^{\mathrm{a}}$ & 0.34 & 0.001 \\
\hline CAT & $42 \pm 0.41$ & $44.75 \pm 0.85$ & $45.25 \pm 0.25$ & 0.24 & 0.100 \\
\hline \multicolumn{6}{|l|}{ Gestation day 150} \\
\hline SOD & $13.76 \pm 0.38^{c}$ & $28.88 \pm 0.64^{b}$ & $39.54 \pm 0.89^{a}$ & 0.47 & 0.001 \\
\hline POD & $215.21 \pm 0.74^{b}$ & $244.11 \pm 0.89^{a}$ & $247.07 \pm 0.98^{a}$ & 0.51 & 0.005 \\
\hline CAT & $45.50 \pm 0.96$ & $47 \pm 0.71$ & $49.50 \pm 0.94$ & 0.49 & 0.154 \\
\hline \multicolumn{6}{|l|}{ Lactation day 20} \\
\hline SOD & $17.97 \pm 0.43^{c}$ & $36.17 \pm 1.05^{\mathrm{b}}$ & $42.76 \pm 0.36^{a}$ & 0.30 & 0.001 \\
\hline POD & $226.91 \pm 0.69^{b}$ & $261.79 \pm 1.55^{\mathrm{a}}$ & $268.11 \pm 0.72^{a}$ & 0.67 & 0.001 \\
\hline CAT & $50.48 \pm 0.87^{c}$ & $55.50 \pm 0.29^{b}$ & $63.39 \pm 0.86^{a}$ & 0.38 & 0.023 \\
\hline
\end{tabular}

Means with superscript letters $(a, b, c)$ within the same row differ significantly at $p \leq 0.05$. SOD, superoxide dismutase; POD, peroxidase; CAT, catalase.

TABLE 6 | Plasma biochemical parameters of Beetal goats.

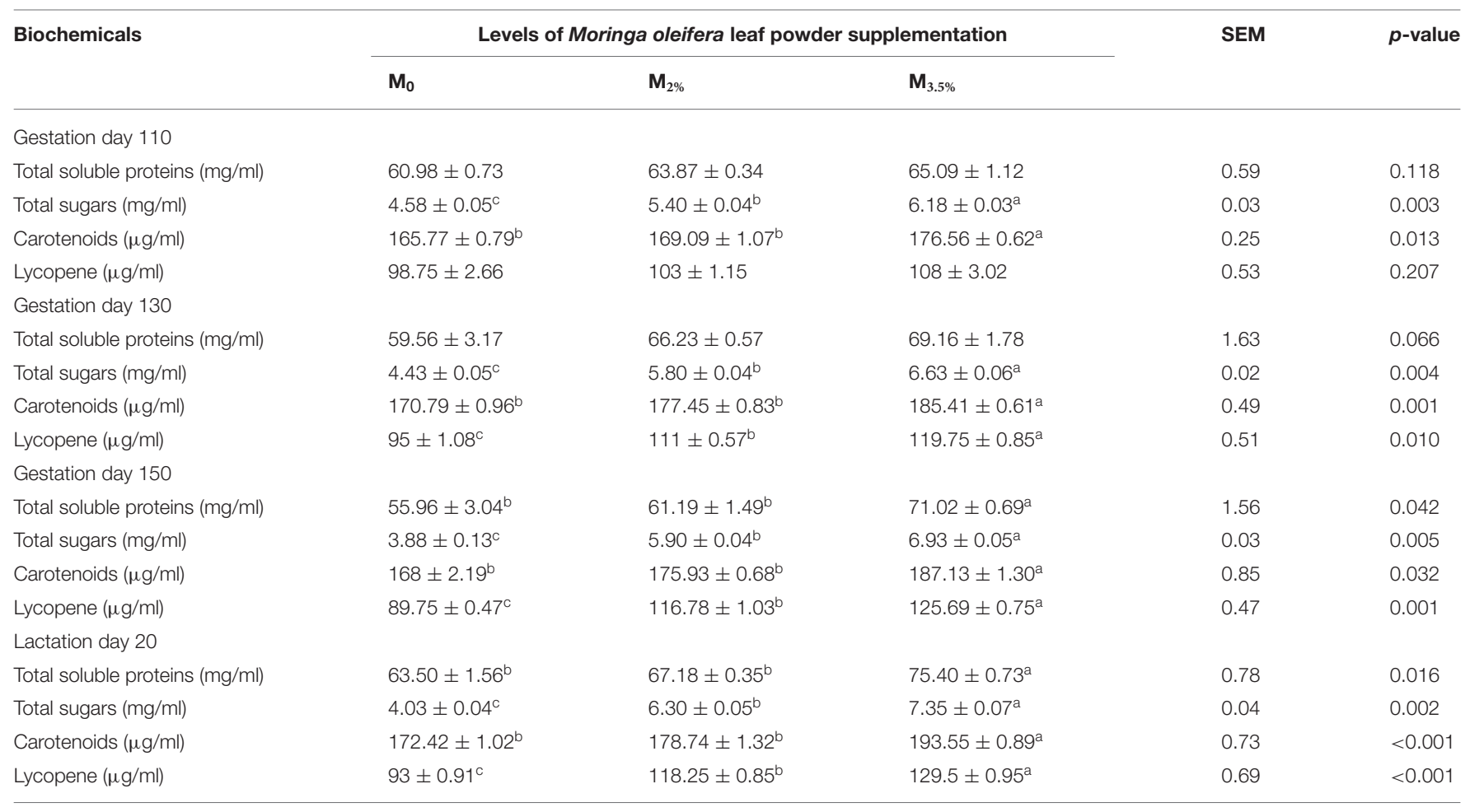

Means with superscript letters $(a, b, c)$ within the same row differ significantly at $p \leq 0.05$.

the $\mathrm{M}_{2 \%}$ group, while these TPCs were improved significantly in the milk samples of the $\mathrm{M}_{2} \%$ group from day 14 to 28 of lactation $(p<0.05)$. The TAC of the milk from $\mathrm{M}_{3.5 \%}$ and $\mathrm{M}_{2 \%}$ groups was significantly increased from the beginning to day 28 of lactation in comparison to the control $\left(\mathrm{M}_{0}\right)$ group $(p<0.05)$. The significant impact of MOLP on colostrum and milk Vit C level was noticed only in the $\mathrm{M}_{3.5 \%}$ group $(p<0.05)$. Both the supplementation levels (3.5 and $2 \%$ ) showed a significant impact 
TABLE 7 | Plasma hydrolytic enzymes activities of Beetal goats.

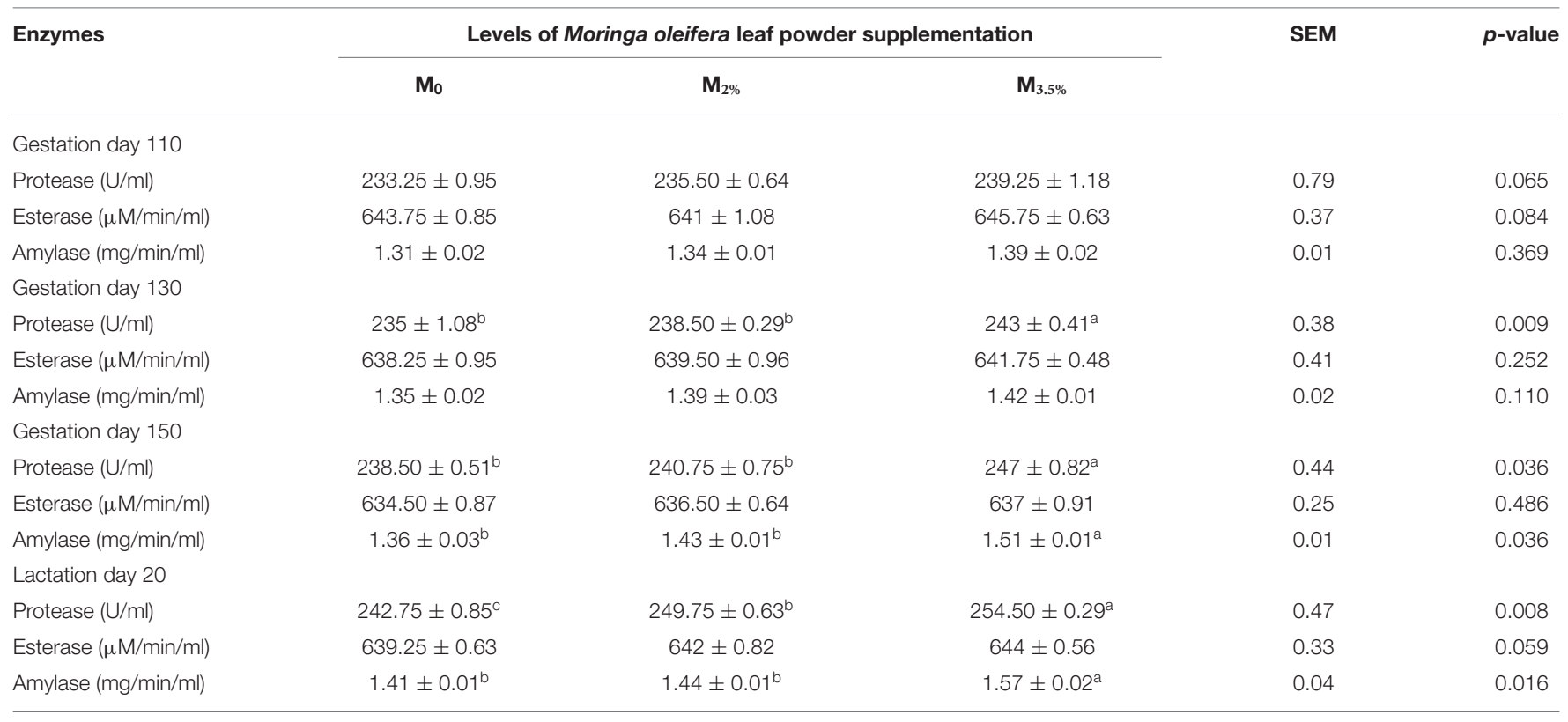

Means with superscript letters $(a, b, c)$ within the same row differ significantly at $p \leq 0.05$.

TABLE 8 | Effect of Moringa oleifera leaf powder supplementation on milk composition.

\begin{tabular}{|c|c|c|c|c|c|}
\hline Biochemical & \multicolumn{3}{|c|}{ Levels of Moringa oleifera leaf powder supplementation } & SEM & $p$-value \\
\hline \multicolumn{6}{|l|}{ Day 0 (Colostrum) } \\
\hline Protein (\%) & $8.93 \pm 0.37^{b}$ & $10.18 \pm 0.28^{b}$ & $13.53 \pm 0.53^{\mathrm{a}}$ & 0.24 & 0.043 \\
\hline Fat (\%) & $8.95 \pm 0.40$ & $9.18 \pm 0.48$ & $9.53 \pm 0.34$ & 0.37 & 0.092 \\
\hline Lactose (\%) & $2.93 \pm 0.29$ & $3.09 \pm 0.31$ & $3.27 \pm 0.13$ & 0.21 & 0.663 \\
\hline Protein (\%) & $6.84 \pm 0.09^{b}$ & $7.11 \pm 0.31^{b}$ & $8.51 \pm 0.25^{a}$ & 0.16 & 0.015 \\
\hline Fat (\%) & $7.38 \pm 0.86$ & $7.94 \pm 0.62$ & $8.72 \pm 0.30$ & 0.61 & 0.233 \\
\hline Lactose (\%) & $3.43 \pm 0.07$ & $3.62 \pm 0.21$ & $3.71 \pm 0.16$ & 0.05 & 0.514 \\
\hline Carotenoids ( $\mu \mathrm{g} / \mathrm{ml})$ & $6.91 \pm 0.19^{b}$ & $7.36 \pm 0.07^{b}$ & $9.82 \pm 0.36^{a}$ & 0.15 & 0.041 \\
\hline \multicolumn{6}{|l|}{ Day 14} \\
\hline Carotenoids ( $\mu \mathrm{g} / \mathrm{ml})$ & $4.68 \pm 0.41^{b}$ & $4.94 \pm 0.16^{b}$ & $6.37 \pm 0.08^{a}$ & 0.2 & 0.022 \\
\hline \multicolumn{6}{|l|}{ Day 21} \\
\hline Protein (\%) & $4.03 \pm 0.13^{c}$ & $5.15 \pm 0.08^{b}$ & $6.56 \pm 0.20^{a}$ & 0.08 & 0.012 \\
\hline Fat (\%) & $4.94 \pm 0.34^{b}$ & $5.32 \pm 0.11^{b}$ & $6.29 \pm 0.16^{a}$ & 0.17 & 0.024 \\
\hline Lactose (\%) & $4.37 \pm 0.51$ & $4.51 \pm 0.58$ & $4.89 \pm 0.78$ & 0.1 & 0.748 \\
\hline Carotenoids $(\mu \mathrm{g} / \mathrm{ml})$ & $2.73 \pm 0.21^{b}$ & $3.02 \pm 0.13^{b}$ & $4.36 \pm 0.11^{a}$ & 0.09 & 0.007 \\
\hline \multicolumn{6}{|l|}{ Day 28} \\
\hline Protein (\%) & $3.43 \pm 0.19^{c}$ & $4.27 \pm 0.11^{b}$ & $5.82 \pm 0.40^{\mathrm{a}}$ & 0.22 & 0.027 \\
\hline Fat (\%) & $4.87 \pm 0.13^{\mathrm{b}}$ & $3.76 \pm 0.15^{b}$ & $3.41 \pm 0.02^{\mathrm{a}}$ & 0.09 & 0.003 \\
\hline Lactose (\%) & $4.95 \pm 0.80$ & $5.08 \pm 0.19$ & $5.35 \pm 0.49$ & 0.15 & 0.917 \\
\hline Carotenoids $(\mu \mathrm{g} / \mathrm{ml})$ & $1.38 \pm 0.36^{b}$ & $1.61 \pm 0.25^{\mathrm{b}}$ & $3.04 \pm 0.08^{a}$ & 0.17 & 0.025 \\
\hline
\end{tabular}

Means with superscript letters $(a, b, c)$ within the same row differ significantly at $p \leq 0.05$. 
TABLE 9 | Effect of Moringa oleifera leaf powder supplementation on milk antioxidant parameters.

\begin{tabular}{|c|c|c|c|c|c|}
\hline \multirow[t]{2}{*}{ Non-enzymatic antioxidants } & \multicolumn{3}{|c|}{ Levels of Moringa oleifera leaf powder supplementation } & \multirow[t]{2}{*}{ SEM } & \multirow[t]{2}{*}{$p$-value } \\
\hline & $\mathbf{M}_{0}$ & $\mathbf{M}_{2 \%}$ & $\mathbf{M}_{3.5 \%}$ & & \\
\hline \multicolumn{6}{|l|}{ Day 0 (Colostrum) } \\
\hline Total phenolic contents $(\mu \mathrm{M} / \mathrm{ml})$ & $2,826.75 \pm 3.49^{b}$ & $2,838.50 \pm 0.64^{b}$ & $2,875.50 \pm 1.55^{\mathrm{a}}$ & 1.06 & 0.002 \\
\hline Total anti-oxidant capacity $(\mu \mathrm{M} / \mathrm{ml})$ & $0.92 \pm 0.02^{\mathrm{C}}$ & $1.42 \pm 0.08^{b}$ & $1.78 \pm 0.13^{a}$ & 0.07 & 0.005 \\
\hline Vitamin $C(\mu \mathrm{g} / \mathrm{ml})$ & $457.75 \pm 1.65^{b}$ & $464.75 \pm 1.79^{b}$ & $483 \pm 0.82^{\mathrm{a}}$ & 0.97 & 0.005 \\
\hline SOD (Units/ml) & $69.86 \pm 0.46^{c}$ & $88.65 \pm 0.69^{b}$ & $96.53 \pm 0.32^{\mathrm{a}}$ & 0.18 & 0.001 \\
\hline POD (Units/ml) & $291.25 \pm 0.63^{b}$ & $309.22 \pm 0.85^{a}$ & $314.02 \pm 1.04^{\mathrm{a}}$ & 0.37 & 0.003 \\
\hline CAT (Units/ml) & $71.75 \pm 0.85$ & $76.75 \pm 1.11$ & $84 \pm 1.78$ & 1.01 & 0.060 \\
\hline \multicolumn{6}{|l|}{ Day 7} \\
\hline Total phenolic contents $(\mu \mathrm{M} / \mathrm{ml})$ & $2,608.85 \pm 2.38^{b}$ & $2,622 \pm 0.71^{b}$ & $2,669.25 \pm 1.88^{a}$ & 0.21 & 0.005 \\
\hline Total anti-oxidant capacity $(\mu \mathrm{M} / \mathrm{ml})$ & $0.81 \pm 0.05^{c}$ & $1.39 \pm 0.12^{b}$ & $1.73 \pm 0.11^{\mathrm{a}}$ & 0.09 & 0.016 \\
\hline Vitamin $C(\mu \mathrm{g} / \mathrm{ml})$ & $421.75 \pm 1.97^{b}$ & $427.25 \pm 1.32^{b}$ & $436.75 \pm 0.75^{a}$ & 0.78 & 0.035 \\
\hline SOD (Units/ml) & $75.75 \pm 0.63^{c}$ & $81.52 \pm 0.26^{b}$ & $94.4 \pm 0.39^{a}$ & 0.16 & 0.001 \\
\hline POD (Units/ml) & $263.45 \pm 0.87^{b}$ & $277.56 \pm 1.32^{\mathrm{a}}$ & $285 \pm 1.65^{\mathrm{a}}$ & 0.28 & 0.015 \\
\hline CAT (Units/ml) & $66.75 \pm 1.37$ & $69.75 \pm 1.18$ & $74 \pm 0.41$ & 0.35 & 0.103 \\
\hline \multicolumn{6}{|l|}{ Day 14} \\
\hline Total phenolic contents ( $\mu \mathrm{M} / \mathrm{ml})$ & $2,471.50 \pm 1.32^{c}$ & $2,493.25 \pm 1.03^{b}$ & $2,547 \pm 2.55^{\mathrm{a}}$ & 1.03 & $<0.001$ \\
\hline Total anti-oxidant capacity $(\mu \mathrm{M} / \mathrm{ml})$ & $0.74 \pm 0.10^{c}$ & $1.29 \pm 0.13^{b}$ & $1.64 \pm 0.12^{a}$ & 0.12 & 0.017 \\
\hline Vitamin $C(\mu \mathrm{g} / \mathrm{ml})$ & $412.70 \pm 1.31^{b}$ & $416.40 \pm 1.28^{b}$ & $429.60 \pm 0.93^{a}$ & 0.71 & 0.016 \\
\hline SOD (Units/ml) & $61.52 \pm 0.31^{c}$ & $74.40 \pm 0.41^{\mathrm{b}}$ & $83.45 \pm 0.55^{\mathrm{a}}$ & 0.33 & $<0.001$ \\
\hline POD (Units/ml) & $251.67 \pm 0.79^{b}$ & $270.92 \pm 1.37^{a}$ & $276.05 \pm 0.96^{a}$ & 0.19 & 0.008 \\
\hline CAT (Units/ml) & $50.61 \pm 1.51$ & $56.75 \pm 1.43$ & $62 \pm 1.92$ & 0.69 & 0.072 \\
\hline \multicolumn{6}{|l|}{ Day 21} \\
\hline Total phenolic contents ( $\mu \mathrm{M} / \mathrm{ml})$ & $2,289 \pm 1.47^{c}$ & $2,326 \pm 0.91^{b}$ & $2,391.50 \pm 0.65^{a}$ & 0.32 & 0.001 \\
\hline Total anti-oxidant capacity $(\mu \mathrm{M} / \mathrm{ml})$ & $0.65 \pm 0.04^{c}$ & $1.24 \pm 0.11^{\mathrm{b}}$ & $1.53 \pm 0.09^{a}$ & 0.08 & 0.013 \\
\hline Vitamin C ( $\mu \mathrm{g} / \mathrm{ml})$ & $385.75 \pm 2.46^{b}$ & $391.50 \pm 1.50^{b}$ & $408.25 \pm 0.75^{\mathrm{a}}$ & 0.57 & 0.021 \\
\hline SOD (Units/ml) & $58.65 \pm 0.69^{c}$ & $63.45 \pm 0.91^{b}$ & $75.04 \pm 0.48^{a}$ & 0.51 & 0.003 \\
\hline POD (Units/ml) & $227.02 \pm 1.08^{c}$ & $243.01 \pm 0.56^{b}$ & $259.66 \pm 0.73^{a}$ & 0.25 & 0.008 \\
\hline CAT (Units/ml) & $37.95 \pm 1.31^{b}$ & $41.98 \pm 0.32^{b}$ & $53.30 \pm 0.61^{a}$ & 0.21 & 0.007 \\
\hline \multicolumn{6}{|l|}{ Day 28} \\
\hline Total phenolic contents $(\mu \mathrm{M} / \mathrm{ml})$ & $2,133 \pm 0.82^{c}$ & $2,173.25 \pm 1.70^{b}$ & $2,205.75 \pm 1.25^{\mathrm{a}}$ & 0.59 & $<0.001$ \\
\hline Total anti-oxidant capacity $(\mu \mathrm{M} / \mathrm{ml})$ & $0.61 \pm 0.13^{c}$ & $1.11 \pm 0.04^{b}$ & $1.37 \pm 0.07^{a}$ & 0.07 & 0.007 \\
\hline Vitamin $C(\mu \mathrm{g} / \mathrm{ml})$ & $374.45 \pm 1.04^{b}$ & $378.70 \pm 0.85^{b}$ & $395.25 \pm 0.69^{a}$ & 0.52 & 0.001 \\
\hline SOD (Units/ml) & $51.70 \pm 0.77^{c}$ & $59.65 \pm 1.05^{b}$ & $66 \pm 0.41^{a}$ & 0.57 & 0.003 \\
\hline POD (Units/ml) & $202.66 \pm 0.68$ & $216.02 \pm 1.12$ & $231.01 \pm 1.31$ & 0.55 & 0.006 \\
\hline CAT (Units/ml) & $29.75 \pm 0.43^{b}$ & $31.36 \pm 0.59^{b}$ & $46 \pm 0.42^{a}$ & 0.26 & 0.002 \\
\hline
\end{tabular}

Means with superscript letters $(a, b, c)$ within the same row differ significantly at $p \leq 0.05$. SOD, superoxide dismutase; POD, peroxidase; CAT, catalase.

on the SOD activity of colostrum and milk samples as compared to the non-supplemented $\left(\mathrm{M}_{0}\right)$ group $(p<0.05)$. Initially, the POD activity was increased significantly irrespective of the level of supplementation. However, from day 21 to 28 of lactation, a significant difference was observed in the improvement of POD activity depending on levels of supplementation. The increase in the activity of CAT enzyme was non-significant up to day 14 of lactation in both $\mathrm{M}_{3.5 \%}$ and $\mathrm{M}_{2 \%}$ groups $(p>0.05)$. However, on days 21 and 28, the supplementation resulted in a significant enhancement in the CAT activity of milk samples from the $\mathrm{M}_{3.5 \%}$ group in comparison to the control $\left(\mathrm{M}_{0}\right)$ group $(p<0.05)$.

\section{Productive and Reproductive Performance}

The supplementation of MOLP increased the milk production in $\mathrm{M}_{3.5 \%}$ and $\mathrm{M}_{2 \%}$ groups as compared to the control $\left(\mathrm{M}_{0}\right)$ group from day 7 to 28 of lactation $(p<0.05)$ as is presented in Table 10. Similarly, the weight gain of kids in supplemented groups was significantly high (Table 11). The results of reproductive parameters (Figures 1, 2) showed that the shedding time of the placenta and the time of onset of first postpartum estrus was less in the goats of $\mathrm{M}_{3.5 \%}$ and $\mathrm{M}_{2} \%$ groups as compared to the goats of the $\left(\mathrm{M}_{0}\right)$ control group. The survival rate and initial birth weight of the kids of $\mathrm{M}_{3.5 \%}$ - and $\mathrm{M}_{2 \%}$-supplemented goats were higher than $\mathrm{M}_{0}$ group goats (Figures 3,4 ). 
TABLE 10 | Effect of Moringa oleifera leaf powder supplementation on milk production (liters) in Beetal goats.

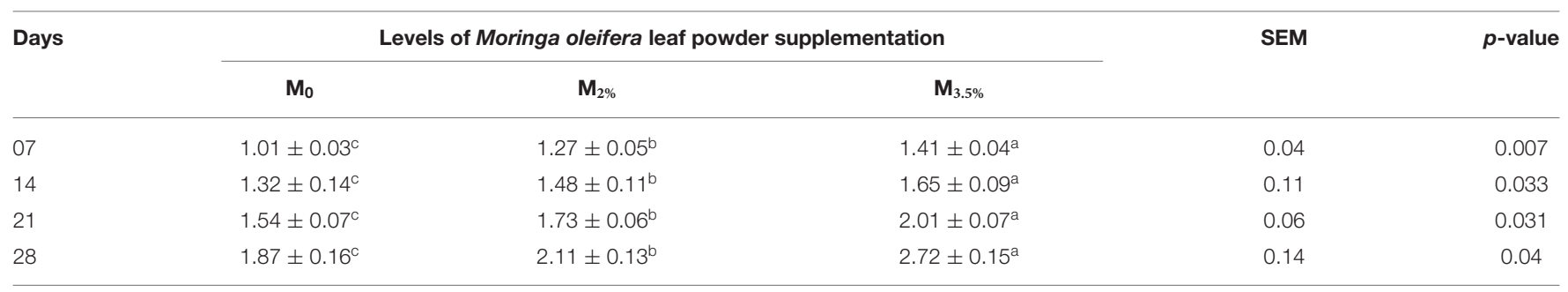

Means with superscript letters $(a, b, c)$ within the same row differ significantly at $p \leq 0.05$.

TABLE 11 | Effect of feeding Moringa oleifera leaf powder supplemented goat milk on body weight (kg) of their kids.

\begin{tabular}{|c|c|c|c|c|c|}
\hline Days & \multicolumn{3}{|c|}{ Levels of Moringa oleifera leaf powder supplementation } & SEM & $p$-value \\
\hline 7 & $2.91 \pm 0.17^{c}$ & $3.77 \pm 0.32^{b}$ & $4.71 \pm 0.28^{a}$ & 0.25 & 0.016 \\
\hline 14 & $3.64 \pm 0.22^{c}$ & $4.51 \pm 0.29^{b}$ & $5.88 \pm 0.12^{\mathrm{a}}$ & 0.2 & 0.001 \\
\hline 21 & $4.49 \pm 0.42^{\mathrm{c}}$ & $5.72 \pm 0.18^{b}$ & $6.96 \pm 0.14^{\mathrm{a}}$ & 0.24 & 0.021 \\
\hline
\end{tabular}

Means with superscript letters $(a, b, c)$ within the same row differ significantly at $p \leq 0.05$.

\section{DISCUSSION}

The animals are more prone to oxidative stress during the transition period because an increase in energy requirements to support developing fetuses and subsequent lactation coincide with depressed feed intake. The nutritional quality of feedstuffs is very important to regulate the pregnancy and lactation performance of goats. The MO leaves are well-known for their nutritional and therapeutic properties that have been attributed to their various phytochemical constituents $(39,40)$.

The pregnancy and lactation stress results in the excessive production of hydroxyl $(\mathrm{OH})$ and nitric oxide $(\mathrm{NO})$ radicals. The animal body is well-equipped with different protective mechanisms to neutralize the harmful effects of $\mathrm{OH}$ and NO radicals. The antioxidant protective system is naturally suppressed near parturition due to certain physiological changes in the body (41). The MOLP supplementation to pregnant goats resulted in an increase in their plasma TFs and TPCs that control the immense production of $\mathrm{OH}$ and $\mathrm{NO}$ radicals via Haber-Weiss and Fenton reactions to minimize the detrimental effects of oxidative stress during pregnancy and lactation (42). The regulation of antioxidant defense system of the body under different stress conditions through MO leaf extract supplementation was also reported in rats (43).

Vitamin C is generally regarded as the first line of defense to provide protection from the damaging effects of oxidative stress in pregnancy especially near parturition (44). A constant decline in plasma vit $C$ level near parturition aggravates the situation that makes the animals more vulnerable to oxidative damage (45). A significant improvement in plasma vit $\mathrm{C}$ level during this study in supplemented goats showed that MOLP as a rich source of vit $\mathrm{C}$ has the ability to protect the pregnant goats from the deleterious effects of oxidative stress by suppressing the action of free radicals. The increase in plasma vit $\mathrm{C}$ concentration in response to MOLP supplementation is in accordance with the findings of a study on Aardi goats (14).

Lipids act as substrate for reactive nitrogen and oxygen species (RNS and ROS) to start the process of lipid peroxidation (LPO) $(46,47)$. The balance between the production and elimination of ROS and RNS from the body is sustained by antioxidant defense system in healthy animals. Any untoward disturbance in this balance may enhance the plasma TOS and MDA concentration. The high values of TOS and MDA represent the state of oxidative stress (48). It is evident from the results of this study that the supplementation of MOLP increased the plasma TAC in treated goats by suppressing the process of LPO. This consequently reduces the values of plasma TOS and MDA. The enzymatic (SOD, POD, and CAT) antioxidants also have a key role in limiting LPO, as both enzymatic and non-enzymatic components of antioxidant defense system work in collaboration to maintain the conditions suitable for mother and developing fetus by minimizing the parturition and early lactation stress (49).

The physiological changes in maternal body during the transition period especially near parturition result in excessive production of ROS (50). These ROS are converted into $\mathrm{H}_{2} \mathrm{O}_{2}$ by SOD enzyme, while POD and CAT enzymes further degrade the $\mathrm{H}_{2} \mathrm{O}_{2}$ into water and molecular oxygen $(51,52)$. The successful completion of parturition stage and start of healthy lactation depend on the activities of SOD, POD, and CAT enzymes (53). High antioxidant (SOD, POD, and CAT) enzyme activities indicate that the supplementation of MOLP in late pregnancy improved the plasma enzymatic antioxidants that was also reported in some other studies conducted with different supplementation levels of $\mathrm{MO}$ in rabbits, poultry, and dairy cows (54-56). 


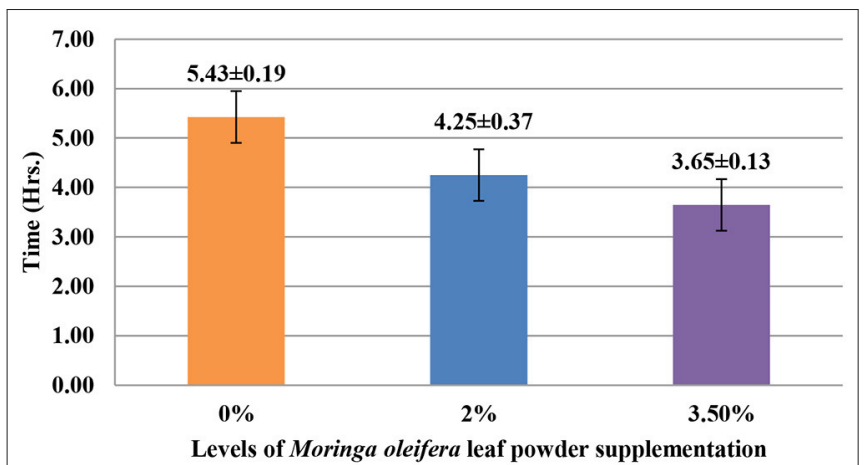

FIGURE 1 | Effect of Moringa oleifera leaf powder supplementation on shedding time (hours) of placenta in Beetal goats.

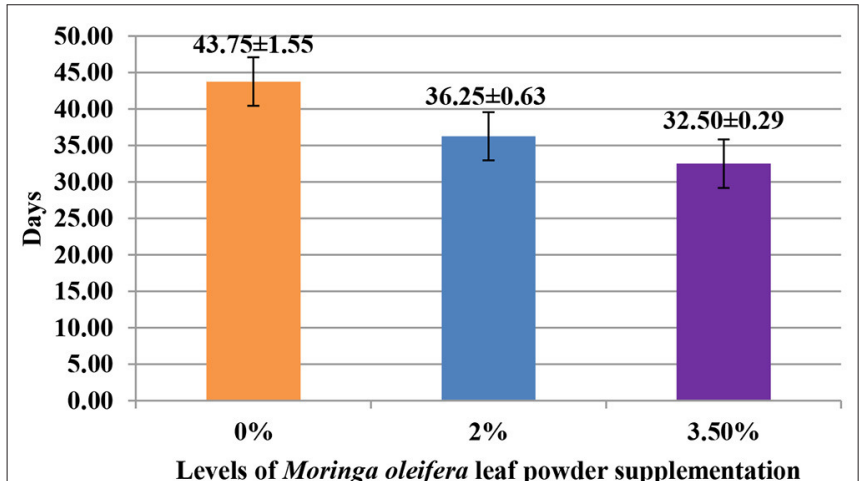

FIGURE 2 | Effect of Moringa oleifera leaf powder supplementation on onset time (days) of first postpartum estrus after kidding in Beetal goats.

Blood biochemical parameters are the established indicators to provide information about the health status of pregnant animals for their successful transfer from gestation to lactation stage (57). Late pregnancy is characterized by severe metabolic changes and a rapid decrease in plasma protein level was also noticed in different other animal species during this period (58-60). The plasma protein level drops promptly in the last trimester due to high amino acid requirements for developing fetus and preparation of the mammary system for subsequent lactation stage (61). However, after parturition, the plasma protein level starts to increase due to immense production of immunoglobulins (62). It is evident from the findings of this study that the plasma protein level was high in supplemented groups as compared to the control group of the experiment during the peripartum period. The supplementation of MOLP increased the plasma protein contents to satisfy the high protein requirements of pregnancy and lactation. These results support the findings of other studies in Jersey cattle and sows $(21,63)$. The presence of high amount of protein in MOLP enhances the synthesis of selenocysteine-based selenoproteins. These proteins have been reported to play a role in the modification of antioxidant defense system and improvement of reproductive functions (64).

The decrease in plasma sugar level near parturition is typical for goats and ewes. A reduction in feed intake occurs during late pregnancy due to the squeezing of the rumen by rapid
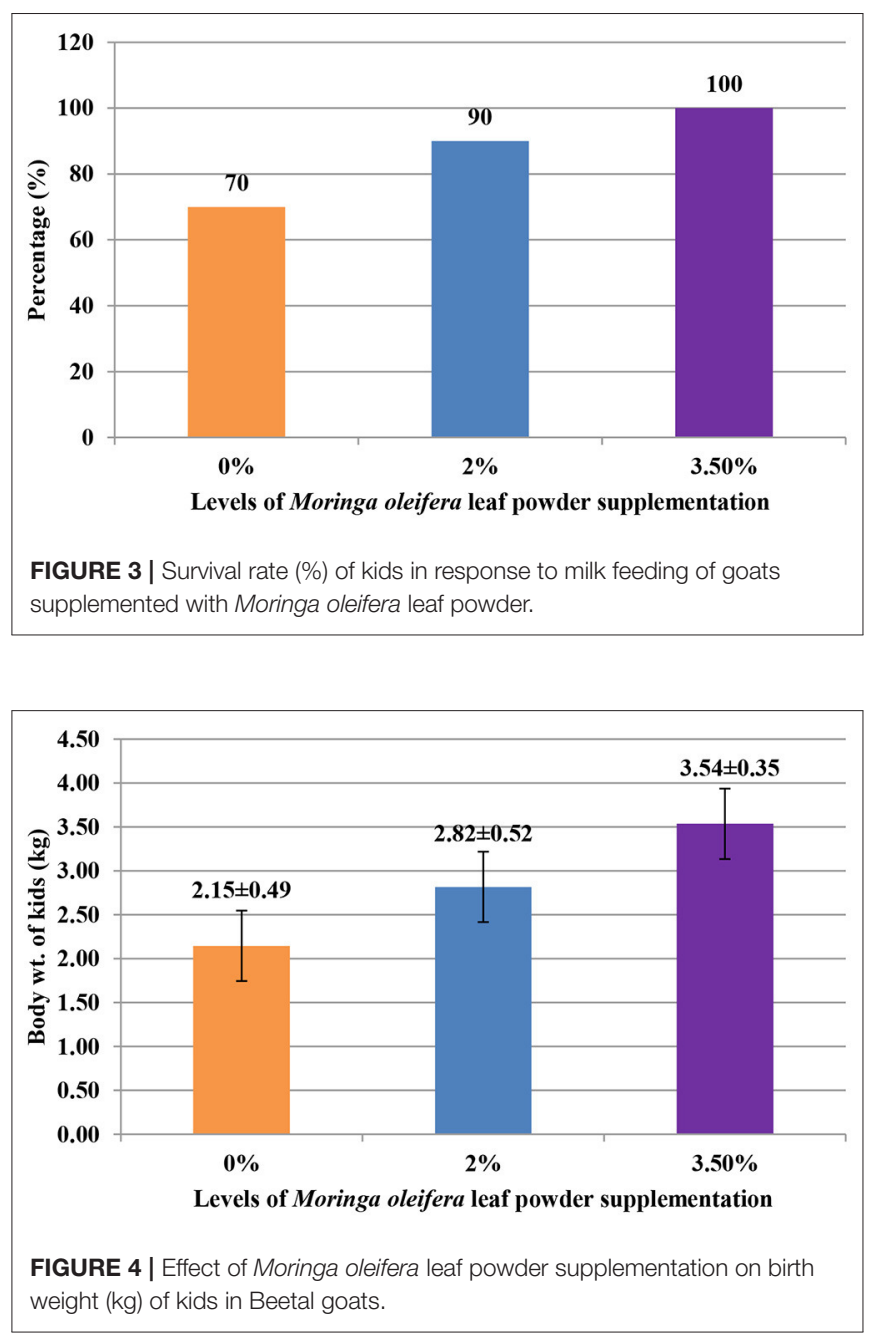

fetal growth (65). The mobilization of the body fats starts if the energy requirements of the animals are not fulfilled with the advancement in pregnancy through provision of appropriate feed supplement (66). The negative energy balance in this stage may lead to the development of ketosis and some other metabolic diseases. The feeding of MOLP increased the plasma sugar level of supplemented groups to provide sufficient amount of energy for parturition and early lactation. The revival of gluconeogenesis process after parturition in response to certain endocrine changes rapidly increase the plasma sugar level $(67,68)$. Furthermore, the supplementation also improved the plasma lycopene and carotenoids status to regulate the synthesis of inflammatory cytokines that reduces the chances of complications at the time of parturition $(69,70)$.

A proteolytic enzyme system in the body helps in the removal of worthless and damaged biomolecules to maintain hemostasis during pregnancy and lactation (71). The significant increase in the activity of protease enzyme in MOLP-supplemented groups depicted its defensive effects at the cellular level. The proteolytic enzyme system is of great importance because it also has the ability to act as a secondary antioxidant defense system when the primary antioxidant system is unable to protect the body from oxidative stress (72). The supplementation of MOLP also resulted 
in an improvement in the amylase activity. This enzyme enhances the conversion of carbohydrates into glucose to produce energy according to the requirements of body during pregnancy and lactation $(66,73)$.

The major outcome of the study was that supplementing the goats' ration with MOLP markedly influenced their colostrum and milk composition. The preparations for colostrum synthesis start in the last month of pregnancy (74). Colostrum provides energy and maternal immunity along with different other growth factors to maintain health status and development of newly born kids. The findings of this study showed that supplementation of MOLP increased the protein contents of colostrum and milk in supplemented groups. The concentration of protein is generally high in colostrum than normal milk due to the presence of Igs in huge amount (75). The consumption of Igs protects the newly born kids from different diseases and thereby enhances their survival rate. The supplementation also improved the fat percentage of mature milk, which is in accordance with the findings of Kholif et al. (76). MOLP stimulates the production of acetate that acts as a major precursor for the biosynthesis of fat (77). Similarly, a significant increase in carotenoids of colostrum and milk was also noticed with 3.5\% supplementation. The concentration of carotenoids in milk mostly depends on the type of feed and MOLP being a rich source of carotenoids has positive effects on the carotenoid contents of colostrum and milk in both supplemented groups. The carotenoids have been reported to play an important role in the improvement of milk quality by preventing the process of auto-oxidation (78).

The presence of antioxidants in appropriate amount prolongs the shelf life of milk and reduces its chances of microbial spoilage. The antioxidants in milk also protect the suckling kids from various health hazards by strengthening their immune system (79). The supplementation of diet with MOLP increased the colostrum and milk TAC as was also reported previously in cows by Kekana et al. (63). This could be due to the synergistic effects of flavonoids, phenolics, Se, and vit C present in MOLP. Generally, milk is not considered a good source of vit C. However, the results of this study showed the presence of an appreciable amount of vit $\mathrm{C}$ in the milk of goats supplemented with MOLP. Thus, feeding the goats with MOLP-supplemented diet positively influenced the vit $\mathrm{C}$ contents in their milk. The presence of functional antioxidants in MOLP also improved the enzymatic (SOD, POD, and CAT) antioxidant status of the milk to fulfill the demands of both milk producers and consumers for healthier dairy products. The favorable impacts of MO supplementation on milk composition were also reported in some other studies performed on dairy animals $(80,81)$.

The beneficial effects of MOLP supplementation on reproductive performance parameters observed in this study were due to its high nutritional profile. The birth weight of kids in supplemented groups was high as compared to the control group. The supplementation of MOLP in advance stage of pregnancy increases the provision of protein to developing fetus for its further growth and also improves the protein contents of colostrum and milk (82). The high level of protein contents in the milk of supplemented goats promoted the weight gain in their kids. The presence of therapeutic compounds in MOLP increased the survival rate of the kids of supplemented goats by protecting them from various diseases (83). Similar findings were reported by Qwele et al. (84), who disclosed that feeding of $\mathrm{MO}$-supplemented diet is beneficial for the animals to protect them from oxidative stress-induced diseases. High milk production in early lactation stage often results in negative energy balance (NEB), if the nutrient supply is inadequate to lactating animals. The NEB is the major cause of delay in shedding of placental membranes and resumption of postpartum estrus after parturition (85). MOLP supplementation improved the energy status of the body to ensure the revival of ovarian activity and reduces postpartum anestrus interval. The shortening of postpartum anestrus duration by dietary modifications has also been reported previously in cows (86). The high proportion of protein and Se contents in MO strengthened the uterine muscle contractions for timely shedding of placenta and thus protects the reproductive tract from different infections.

\section{CONCLUSION}

The results of the current study revealed that supplementing 3.5\% MOLP improved maternal health and milk quality in terms of antioxidant status and biochemical composition. Furthermore, this supplementation level also increased the milk yield, kids' growth rate, and reproductive performance of goats. These findings propose that MOLP has the potential to improve the productive/reproductive performance of goats. However, further studies are required with different feeding levels of MOLP to explore the molecular aspects of improving productive and reproductive performance in large herds of animals.

\section{AUTHOR'S NOTE}

This experiment/research paper is a part of Ali Afzal PhD study.

\section{DATA AVAILABILITY STATEMENT}

The raw data supporting the conclusions of this article will be made available by the authors, without undue reservation.

\section{ETHICS STATEMENT}

The procedures used for study and ethical clearance was approved and granted by Animal Use and Care Research Committee at Nuclear Institute for Agriculture and Biology (NIAB), Faisalabad, Pakistan.

\section{AUTHOR CONTRIBUTIONS}

AA: conduct experiment, data aggregation, statistical analysis, and wrote manuscript. AH: lab analysis. TH: design experiment, monitoring experiment, and revised manuscript. MS and MM: methodology. GY: manuscript editing and revision. All authors contributed to the article and approved the submitted version.

\section{ACKNOWLEDGMENTS}

The authors pay their special thanks to NIAB-C, PIEAS management for their help to complete the research work. 


\section{REFERENCES}

1. Abuelo A, Hernández J, Benedito JL, Castillo C. Redox biology in transition periods of dairy cattle: Role in the health of periparturient and neonatal animals. Antioxidants. (2019) 8:20-39. doi: 10.3390/antiox8010020

2. Sordillo LM. Nutritional strategies to optimize dairy cattle immunity. J Dairy Sci. (2016) 99:4967-82. doi: 10.3168/jds.2015-10354

3. Berchieri-Ronchi CB, Presti PT, Ferreira AL, Correa CR, Salvadori DM, Damasceno DC, et al. Effects of oxidative stress during human and animal reproductions: a review. Int $J$ Nutr. (2015) 8:6-11. doi: $10.1055 / \mathrm{s}-0040-1705063$

4. Idamokoro EM, Muchenje V, Afolayan AJ, Hugo A. Comparative fattyacid profile and atherogenicity index of milk from free grazing Nguni, Boer and non-descript goats in South Africa. Pastoralism. (2019) 9:18. doi: 10.1186/s13570-019-0138-8

5. Obrador E, Liu-Smith F, Dellinger RW, Salvador R, Meyskens FL, Estrela JM. Oxidative stress and antioxidants in the pathophysiology of malignant melanoma. Biol Chem. (2019) 400:589-612. doi: 10.1515/hsz-2018-0327

6. Vitale SG, Capriglione S, Peterlunger I, La Rosa VL, Vitagliano A, Noventa $\mathrm{M}$, et al. The role of oxidative stress and membrane transport systems during endometriosis: a fresh look at a busy corner. Oxid Med Cell Longev. (2018) 2018:1-14. doi: 10.1155/2018/7924021

7. Colitti M, Stefanon B, Gabai G, Gelain ME, Bonsembiante F. Oxidative stress and nutraceuticals in the modulation of the immune function: current knowledge in animals of veterinary interest. Antioxidants. (2019) 8:28. doi: $10.3390 /$ antiox 8010028

8. Hernández-Castellano LE, Morales-delaNuez A, Sánchez-Macías D, MorenoIndias I, Torres A, Capote J, et al. The effect of colostrum source (goat vs sheep) and timing of the first colostrum feeding ( $2 \mathrm{~h}$ vs $14 \mathrm{~h}$ after birth) on body weight and immune status of artificially reared newborn lambs. J Dairy Sci. (2015) 98:204-10. doi: 10.3168/jds.2014-8350

9. Zachwieja A, Szulc T, Potkański A, Mikuła R, Kruszyński W, Dobicki A. Effect of different fat supplements used during dry period of cows on colostrum physicochemical properties. Biotechnol Anim Husb. (2007) 23:6775. doi: 10.2298/BAH0702067Z

10. Hyrslova I, Krausova G, Bartova J, Kolesar L, Curda L. Goat and bovine colostrum as a basis for new probiotic functional foods and dietary supplements. J Microb Biochem Technol. (2016) 8:56-9. doi: 10.4172/1948-5948.1000262

11. Kekana TW, Nherera-Chokuda VF, Baloyi JJ, Muya CM. Immunoglobulin $G$ response and performance in Holstein calves supplemented with garlic powder and probiotics. S Afr J Anim Sci. (2020) 50:263-70. doi: 10.4314/sajas.v50i2.9

12. Kholif AE, Morsy TA, Gouda GA, Anele UY, Galyean ML. Effect of feeding diets with processed Moringa oleifera meal as protein source in lactating Anglo-Nubian goats. Anim Feed Sci Technol. (2016) 217:4555. doi: 10.1016/j.anifeedsci.2016.04.012

13. Abou-Elkhair R, Mahboub H, Sadek K, Ketkat S. Effect of prepartum dietary energy source on goat maternal metabolic profile, neonatal performance, and economic profitability. J Adv Vet Anim Res. (2020) 7:56674. doi: 10.5455/javar.2020.g454

14. Al-Juhaimi FY, Alsawmahi ON, Abdoun KA, Ghafoor K, Babiker EE. Antioxidant potential of Moringa leaves for improvement of milk and serum quality of Aardi goats. S Afr J Bot. (2020) 129:134-37. doi: 10.1016/j.sajb.2019.03.022

15. Patra AK, Amasheh S, Aschenbach JR. Modulation of gastrointestinal barrier and nutrient transport function in farm animals by natural plant bioactive compounds-a comprehensive review. Crit Rev Food Sci Nutr. (2019) 59:323766. doi: 10.1080/10408398.2018.1486284

16. Abbas RK, Elsharbasy FS, Fadlelmula AA. Nutritional values of Moringa oleifera, total protein. amino acid, vitamins, minerals, carbohydrates, total fat and crude fiber, under the semi-arid conditions of Sudan. J Microb Biochem Technol. (2018) 10:56-8. doi: 10.4172/1948-5948.1000396

17. Kou X, Li B, Olayanju JB, Drake JM, Chen N. Nutraceutical or pharmacological potential of Moringa oleifera Lam. Nutrients. (2018) 10:343. doi: 10.3390/nu10030343

18. Saleem A, Saleem M, Akhtar MF. Antioxidant, anti-inflammatory and antiarthritic potential of Moringa oleifera Lam: an ethnomedicinal plant of Moringaceae family. S Afr J Bot. (2020) 128:24656. doi: 10.1016/j.sajb.2019.11.023

19. Vats S, Gupta T. Evaluation of bioactive compounds and antioxidant potential of hydroethanolic extract of Moringa oleifera Lam. from Rajasthan, India. Physiol Mol Biol Plants. (2017) 23:239-48. doi: 10.1007/s12298-016-0407-6

20. Zeng B, Luo J, Wang P, Yang L, Chen T, Sun J, et al. The beneficial effects of Moringa oleifera leaf on reproductive performance in mice. Food Sci Nutr. (2019) 7:738-46. doi: 10.1002/fsn3.918

21. Sun JJ, Wang P, Chen GP, Luo JY, Xi QY, Cai GY, et al. Effect of Moringa oleifera supplementation on productive performance, colostrum composition and serum biochemical indexes of sow. J Anim Physiol Anim Nutr. (2020) 104:291-9. doi: 10.1111/jpn.13224

22. Afzal A, Hussain T, Hameed A. Moringa oleifera supplementation improves antioxidant status and biochemical indices by attenuating early pregnancy stress in Beetal goats. Front Nutr. (2021) 8:700957. doi: 10.3389/fnut.2021.700957

23. NRC. Nutrient Requirements of Small Ruminants: Sheep, Goats, Cervids, and New World Camelids. Washington DC: National Academy Press (2007).

24. AOAC. Association of Official Analytical Chemist. Official Methods of Analysis. 21st ed. Vol. 222. Washington, DC: Association of Official Analytical Chemists (2005).

25. Lin JY, Tang CY. Determination of total phenolic and flavonoid contents in selected fruits and vegetables, as well as their stimulatory effects on mouse splenocyte proliferation. Food Chem. (2007) 101:140-7. doi: 10.1016/j.foodchem.2006.01.014

26. Ainsworth EA, Gillespie KM. Estimation of total phenolic content and other oxidation substrates in plant tissues using Folin-Ciocalteu reagent. Nat protoc. (2007) 2:875-77. doi: 10.1038/nprot.2007.102

27. Moeslinger T, Brunner M, Volf I, Spieckermann PG. Spectrophotometric determination of ascorbic acid and dehydroascorbic acid. Clin Chem. (1995) 41:1177-81. doi: 10.1093/clinchem/41.8.1177

28. Dhindsa RS, Plumb-Dhindsa PA, Thorpe TA. Leaf senescence: correlated with increased levels of membrane permeability and lipid peroxidation, and decreased levels of superoxide dismutase and catalase. J Exp Bot. (1981) 32:93-101. doi: 10.1093/jxb/32.1.93

29. Dikilitas M, Guldur ME, Deryaoglu A, Ozcan ER. Antioxidant and oxidant levels of pepper (Capsicum annuum cv. Charlee) infected with pepper mild mottle virus. Not Bot Horti Agrobo. (2011) 39:58-63. doi: 10.15835/nbha3925881

30. Beyer WF Jr, Fridovich I. Assaying for superoxide dismutase activity: some large consequences of minor changes in conditions. Anal Biochem. (1987) 161:559-66. doi: 10.1016/0003-2697(87)90489-1

31. Agostini E, Medina MI, Milrad de Forchetti SR, Tigier H. Properties of two anionic peroxidase isoenzymes from turnip (Brassica napus L.) roots. J Agric Food Chem. (1997) 45:596-8. doi: 10.1021/jf960259u

32. Beers RF, Sizer IW, A. spectrophotometric method for measuring the breakdown of hydrogen peroxide by catalase. J Biol Chem. (1952) 195:13340. doi: 10.1016/S0021-9258(19)50881-X

33. Bradford MM, A. rapid and sensitive method for the quantitation of microgram quantities of protein utilizing the principle of protein-dye binding. Anal Biochem. (1976) 72:248-54. doi: 10.1016/0003-2697(76)90527-3

34. Folin O. Two revised copper methods for blood sugar determination. J Biol Chem. (1929) 82:83-93. doi: 10.1016/S0021-9258(18)63690-7

35. Nagata M, Yamashita I. Simple method for simultaneous determination of chlorophyll and carotenoids in tomato fruit. Nippon Shokuhin Kogyo Gakkaishi. (1992) 39:925-8. doi: 10.3136/nskkk1962.39.925

36. Peterson GL, A. simplification of the protein assay method of Lowry et al. which is more generally applicable. Anal Biochem. (1977) 83:34656. doi: 10.1016/0003-2697(77)90043-4

37. Van Asperen K, A. study of housefly esterases by means of a sensitive colorimetric method. J Insect Physiol. (1962) 8:401-16. doi: 10.1016/0022-1910(62)90074-4

38. Filner P, Varner JE. A test for de novo synthesis of enzymes: density labeling with $\mathrm{H} 2 \mathrm{O} 18$ of barley alpha-amylase induced by gibberellic acid. Proc Natl Acad Sci USA. (1967) 58:1520. doi: 10.1073/pnas.58.4.1520

39. Vongsak B, Sithisarn P, Mangmool S, Thongpraditchote S, Wongkrajang Y, Gritsanapan W. Maximizing total phenolics, total flavonoids contents and antioxidant activity of Moringa oleifera leaf extract 
by the appropriate extraction method. Ind Crops Prod. (2013) 44:566-71. doi: 10.1016/j.indcrop.2012.09.021

40. Verma AR, Vijayakumar M, Mathela CS, Rao CV. In vitro and in vivo antioxidant properties of different fractions of Moringa oleifera leaves. Food Chem Toxicol. (2009) 47:2196-201. doi: 10.1016/j.fct.2009.06.005

41. Sharma N, Singh NK, Singh OP, Pandey V, Verma PK. Oxidative stress and antioxidant status during transition period in dairy cows. AsianAustr J Anim Sci. (2011) 24:479-84. doi: 10.5713/ajas.2011.10220

42. Zhang LY, Cosma G, Gardner H, Vallyathan V, Castranova V. Effect of chlorogenic acid on hydroxyl radical. Mol Cell Biochem. (2003) 247:20510. doi: 10.1023/a:1024103428348

43. Aekthammarat D, Pannangpetch P, Tangsucharit P. Moringa oleifera leaf extract lowers high blood pressure by alleviating vascular dysfunction and decreasing oxidative stress in L-NAME hypertensive rats. Phytomedicine. (2019) 54:9-16. doi: 10.1016/j.phymed.2018.10.023

44. Hassan HM, El-Moniary MM, Hamouda Y, El-Daly EF, Youssef AW, Abd El-Azeem NA. Effect of different levels of Moringa oleifera leaves meal on productive performance, carcass characteristics and some blood parameters of broiler chicks reared under heat stress conditions. Asian J Anim Vet Adv. (2016) 11:60-6. doi: 10.3923/ajava.2016.60.66

45. Rao GM, Sumita P, Roshni M, Ashtagimatt MN. Plasma antioxidant vitamins and lipid peroxidation products in pregnancy induced hypertension. Indian J Clin Biochem. (2005) 20:198-200. doi: 10.1007/BF02893070

46. Mello LD, Kubota LT. Biosensors as a tool for the antioxidant status evaluation. Talanta. (2007) 72:335-48. doi: 10.1016/j.talanta.2006.11.041

47. Kale M, Rathore N, John S, Bhatnagar D. Lipid peroxidative damage on pyrethroid exposure and alterations in antioxidant status in rat erythrocytes: a possible involvement of reactive oxygen species. Toxicol Lett. (1999) 105:197205. doi: 10.1016/S0378-4274(98)00399-3

48. Konvičná J, Vargová M, Paulíková I, Kováč G, Kostecká Z. Oxidative stress and antioxidant status in dairy cows during prepartal and postpartal periods. Acta Veterinaria Brno. (2015) 84:133-40. doi: 10.2754/avb201584020133

49. Gong J, Xiao M. Effect of organic selenium supplementation on selenium status, oxidative stress, and antioxidant status in selenium-adequate dairy cows during the periparturient period. Biol Trace Elem Res. (2018) 186:43040. doi: 10.1007/s12011-018-1323-0

50. Radin L, Šimpraga M, Vince S, Kostelić A, Milinković-Tur S. Metabolic and oxidative status of Saanen goats of different parity during the peripartum period. J Dairy Res. (2015) 82:426-33. doi: 10.1017/S0022029915000552

51. Al-Gubory KH, Fowler PA, Garrel C. The roles of cellular reactive oxygen species, oxidative stress and antioxidants in pregnancy outcomes. Int $J$ Biochem Cell Biol. (2010) 42:1634-50. doi: 10.1016/j.biocel.2010.06.001

52. El-Demerdash FM. Antioxidant effect of vitamin E and selenium on lipid peroxidation, enzyme activities and biochemical parameters in rats exposed to aluminium. J Trace Elem Med Biol. (2004) 18:11321. doi: 10.1016/j.jtemb.2004.04.001

53. Karapehlivan M, Kaya I, Sag A, Akin S, Ozcan A. Effects of early and late lactation period on plasma oxidant/antioxidant balance of goats. Kafkas Univ Vet Fak Derg. (2013) 19:529-33.

54. Kekana TW, Marume U, Muya MC, Nherera-Chokuda FV. Periparturient antioxidant enzymes, haematological profile and milk production of dairy cows supplemented with Moringa oleifera leaf meal. Anim Feed Sci Technol. (2020) 268:114606. doi: 10.1016/j.anifeedsci.2020.114606

55. Sun B, Zhang Y, Ding M, Xi Q, Liu G, Li Y, et al. Effects of Moringa oleifera leaves as a substitute for alfalfa meal on nutrient digestibility, growth performance, carcass trait, meat quality, antioxidant capacity and biochemical parameters of rabbits. J Anim Physiol Anim Nutr. (2018) 102:194203. doi: 10.1111/jpn.12678

56. Cui YM, Wang J, Lu W, Zhang HJ, Wu SG Qi GH. Effect of dietary supplementation with Moringa oleifera leaf on performance, meat quality, and oxidative stability of meat in broilers. Poultry Sci. (2018) 97:283644. doi: $10.3382 /$ ps/pey122

57. Guo J, Peters RR, Kohn RA. Effect of a transition diet on production performance and metabolism in periparturient dairy cows. J Dairy Sci. (2007) 90:5247-58. doi: $10.3168 /$ jds.2007-0326

58. Janku L, Pavlata L, Mišurová L, Filípek J, Pechová A, Dvorák R. Levels of protein fractions in blood serum of periparturient goats. Acta Veterinaria Brno. (2011) 80:185-90. doi: 10.2754/avb201180020185
59. Ibrahim MA, Abdelrahman $H$, Elmetwaly H. Hormonal profile, antioxidant status and some biochemical parameters during pregnancy and periparturient period in dromedary she camel. Egypt J Vet Sci. (2017) 48:81-94. doi: 10.21608/ejvs.2017.2040.1022

60. Tóthová C, Nagy O, Nagyová V, Kováč G. Serum protein electrophoretic pattern in dairy cows during the periparturient period. J Appl Anim Res. (2018) 46:33-8. doi: 10.1080/09712119.2016.1256293

61. Ateya A, El-Sayed A, Mohamed R. Gene expression and serum profile of antioxidant markers discriminate periparturient period time in dromedary camels. Mammal Res. (2021) 66:603-13. doi: 10.1007/s13364-021-00578-3

62. Tharwat M, Ali A, Al-Sobayil F. Hematological and biochemical profiles in goats during the transition period. Comp Clin Path. (2015) 24:17. doi: $10.1007 / \mathrm{s} 00580-013-1842-1$

63. Kekana TW, Marume U, Muya CM, Nherera-Chokuda FV. Lactation performance and blood metabolites in lactating dairy cows microsupplemented with Moringa oleifera leaf meal. S Afr J Anim Sci. (2019) 49:709-16. doi: 10.4314/sajas.v49i4.12

64. Mehdi Y, Hornick JL, Istasse L, Dufrasne I. Selenium in the environment, metabolism and involvement in body functions. Molecules. (2013) 18:3292311. doi: 10.3390/molecules 18033292

65. Castagnino DD, Härter CJ, Rivera AR, Lima LD, Silva HG, Biagioli $\mathrm{B}$, et al. Changes in maternal body composition and metabolism of dairy goats during pregnancy. Brazilian J Anim Sci. (2015) 44:92102. doi: $10.1590 /$ S1806-92902015000300003

66. Caré S, Trevisi E, Minuti A, Ferrari A, Loor JJ, Calamari L. Plasma fructosamine during the transition period and its relationship with energy metabolism and inflammation biomarkers in dairy cows. Livest Sci. (2018) 216:138-47. doi: 10.1016/j.livsci.2018.08.003

67. Hashizume T, Takahashi Y, Numata M, Sasaki K, Ueno K, Ohtsuki K, et al. Plasma profiles of growth hormone, prolactin and insulin-like growth factorI during gestation, lactation and the neonatal period in goats. J Reprod Dev. (1999) 45:273-81. doi: 10.1262/jrd.45.273

68. Bell AW, Bauman DE. Adaptations of glucose metabolism during pregnancy and lactation. J Mammary Gland Biol Neoplasia. (1997) 2:26578. doi: 10.1023/A:1026336505343

69. Ishola IO, Yemitan KO, Afolayan OO, Anunobi CC, Durojaiye TE. Potential of Moringa oleifera in the treatment of benign prostate hyperplasia: role of antioxidant defence systems. Med Princ Prac. (2018) 27:1522. doi: $10.1159 / 000486349$

70. Kilany OE, Abdelrazek HM, Aldayel TS, Abdo S, Mahmoud MM. Antiobesity potential of Moringa olifera seed extract and lycopene on high fat diet induced obesity in male Sprauge Dawely rats. Saudi J Biol Sci. (2020) 27:2733-46. doi: 10.1016/j.sjbs.2020.06.026

71. Petushkova AI, Zamyatnin AA. Redox-mediated post-translational modifications of proteolytic enzymes and their role in protease functioning. Biomolecules. (2020) 10:650. doi: 10.3390/biom10040650

72. Bota DA, Davies KJ. Protein degradation in mitochondria: implications for oxidative stress, aging and disease: a novel etiological classification of mitochondrial proteolytic disorders. Mitochondrion. (2001) 1:33-49. doi: 10.1016/S1567-7249(01)00005-8

73. Khan JR, Ludri RS. Changes in blood glucose, plasma non-esterified fatty acids and insulin in pregnant and non-pregnant goats. Trop Anim Health Prod. (2002) 34:81-90. doi: 10.1023/a:1013798114081

74. Banchero GE, Clariget RP, Bencini R, Lindsay DR, Milton JT, Martin GB. Endocrine and metabolic factors involved in the effect of nutrition on the production of colostrum in female sheep. Reprod Nutr Dev. (2006) 46:44760. doi: 10.1051/rnd:2006024

75. Moreno-Indias I, Sánchez-Macías D, Castro N, Morales-delaNuez A, Hernández-Castellano LE, Capote J, Argüello A. Chemical composition and immune status of dairy goat colostrum fractions during the first $10 \mathrm{~h}$ after partum. Small Rumin Res. (2012) 103:220-4. doi: 10.1016/j.smallrumres.2011.09.015

76. Kholif AE, Gouda GA, Olafadehan OA, Abdo MM. Effects of replacement of Moringa oleifera for berseem clover in the diets of Nubian goats on feed utilisation, and milk yield, composition and fatty acid profile. Animal. (2018) 12:964-72. doi: $10.1017 /$ S1751731117002336

77. Babiker EE, Juhaimi FA, Ghafoor K, Mohamed HE, Abdoun KA. Effect of partial replacement of alfalfa hay with Moringa species leaves on milk yield 
and composition of Najdi ewes. Trop Anim Health Prod. (2016) 48:142733. doi: 10.1007/s11250-016-1111-9

78. Stahl W, Sies H. Antioxidant activity of carotenoids. Mol Aspects Med. (2003) 24:345-51. doi: 10.1016/S0098-2997(03)00030-X

79. Aguiar SC, Cottica SM, Boeing JS, Samensari RB, Santos GT, Visentainer JV, et al. Effect of feeding phenolic compounds from propolis extracts to dairy cows on milk production, milk fatty acid composition, and the antioxidant capacity of milk. Anim Feed Sci Tech. (2014) 193:14854. doi: 10.1016/j.anifeedsci.2014.04.006

80. Zeng B, Sun JJ, Chen T, Sun BL, He Q, Chen XY, et al. Effects of Moringa oleifera silage on milk yield, nutrient digestibility and serum biochemical indexes of lactating dairy cows. J Anim Physiol Anim Nutr. (2018) 102:7581. doi: $10.1111 /$ jpn. 12660

81. Dong L, Zhang T, Diao Q. Effect of dietary supplementation of Moringa oleifera on the production performance and fecal methanogenic community of lactating dairy cows. Animals. (2019) 9:262. doi: 10.3390/ani9050262

82. Kholif AE, Gouda GA, Morsy TA, Salem AZ, Lopez S, Kholif AM. Moringa oleifera leaf meal as a protein source in lactating goat's diets: feed intake, digestibility, ruminal fermentation, milk yield and composition, and its fatty acids profile. Small Rumin Res. (2015) 129:12937. doi: 10.1016/j.smallrumres.2015.05.007

83. Asaolu V, Binuomote R, Akinlade J, Aderinola O, Oyelami O. Intake and growth performance of West African Dwarf goats fed Moringa oleifera, Gliricidia sepium and Leucaena leucocephala dried leaves as supplements to cassava peels. J Biol Agric Healthc. (2012) 2:76-88.

84. Qwele K, Hugo A, Oyedemi SO, Moyo B, Masika PJ, Muchenje V. Chemical composition, fatty acid content and antioxidant potential of meat from goats supplemented with Moringa (Moringa oleifera) leaves, sunflower cake and grass hay. Meat Sci. (2013) 93:455-62. doi: 10.1016/j.meatsci.2012.11.009

85. Butler WR. Nutritional interactions with reproductive performance in dairy cattle. Anim Reprod Sci. (2000) 60:44957. doi: 10.1016/S0378-4320(00)00076-2

86. Vu DD, Dung CA, Hai PH. Use of urea-molasses-multinutrient block and urea-treated rice straw for improving dairy cattle productivity in Vietnam. Prev Vet Med. (1999) 38:187-93. doi: 10.1016/S0167-5877(98)00124-X

Conflict of Interest: The authors declare that the research was conducted in the absence of any commercial or financial relationships that could be construed as a potential conflict of interest.

Publisher's Note: All claims expressed in this article are solely those of the authors and do not necessarily represent those of their affiliated organizations, or those of the publisher, the editors and the reviewers. Any product that may be evaluated in this article, or claim that may be made by its manufacturer, is not guaranteed or endorsed by the publisher.

Copyright (c) 2022 Afzal, Hussain, Hameed, Shahzad, Mazhar and Yang. This is an open-access article distributed under the terms of the Creative Commons Attribution License (CC BY). The use, distribution or reproduction in other forums is permitted, provided the original author(s) and the copyright owner(s) are credited and that the original publication in this journal is cited, in accordance with accepted academic practice. No use, distribution or reproduction is permitted which does not comply with these terms. 